\title{
Representing life in the Earth system with soil microbial functional traits in the MIMICS model
}

\author{
W. R. Wieder ${ }^{1,2}$, A. S. Grandy ${ }^{3}$, C. M. Kallenbach ${ }^{3}$, P. G. Taylor ${ }^{2,4}$, and G. B. Bonan ${ }^{1}$ \\ ${ }^{1}$ Climate and Global Dynamics Division, National Center for Atmospheric Research, Boulder, CO, USA \\ ${ }^{2}$ Institute for Arctic and Alpine Research, University of Colorado, Boulder, CO, USA \\ ${ }^{3}$ Department of Natural Resources and the Environment, University of New Hampshire, Durham, NH, USA \\ ${ }^{4}$ Nicholas School of the Environment, Duke University, Durham, NC, USA
}

Correspondence to: W. R. Wieder (wwieder@ucar.edu)

Received: 31 January 2015 - Published in Geosci. Model Dev. Discuss.: 25 February 2015

Revised: 17 May 2015 - Accepted: 20 May 2015 - Published: 17 June 2015

\begin{abstract}
Projecting biogeochemical responses to global environmental change requires multi-scaled perspectives that consider organismal diversity, ecosystem processes, and global fluxes. However, microbes, the drivers of soil organic matter decomposition and stabilization, remain notably absent from models used to project carbon (C) cycleclimate feedbacks. We used a microbial trait-based soil $\mathrm{C}$ model with two physiologically distinct microbial communities, and evaluate how this model represents soil $\mathrm{C}$ storage and response to perturbations. Drawing from the application of functional traits used to model other ecosystems, we incorporate copiotrophic and oligotrophic microbial functional groups in the MIcrobial-MIneral Carbon Stabilization (MIMICS) model; these functional groups are akin to "gleaner" vs. "opportunist" plankton in the ocean, or $r$ vs. $K$-strategists in plant and animal communities. Here we compare MIMICS to a conventional soil C model, DAYCENT (the daily time-step version of the CENTURY model), in cross-site comparisons of nitrogen $(\mathrm{N})$ enrichment effects on soil $\mathrm{C}$ dynamics. MIMICS more accurately simulates $\mathrm{C}$ responses to $\mathrm{N}$ enrichment; moreover, it raises important hypotheses involving the roles of substrate availability, community-level enzyme induction, and microbial physiological responses in explaining various soil biogeochemical responses to $\mathrm{N}$ enrichment. In global-scale analyses, we show that MIMICS projects much slower rates of soil $\mathrm{C}$ accumulation than a conventional soil biogeochemistry in response to increasing $\mathrm{C}$ inputs with elevated carbon dioxide $\left(\mathrm{CO}_{2}\right)$ - a finding that would reduce the size of the land $\mathrm{C}$ sink estimated by the Earth system. Our findings illustrate
\end{abstract}

that tradeoffs between theory and utility can be overcome to develop soil biogeochemistry models that evaluate and advance our theoretical understanding of microbial dynamics and soil biogeochemical responses to environmental change.

\section{Introduction}

Soil contains the largest terrestrial pool of carbon (C) on Earth, and it is susceptible to environmental change. Earth system models (ESMs) show high uncertainty in their representation of current stocks and projected changes of soil $\mathrm{C}$ dynamics, and inadequately capture soil $\mathrm{C}$ cycle-climate change feedbacks (Todd-Brown et al., 2013, 2014). This uncertainty reflects, in part, the mismatch between model assumptions and our contemporary understanding of soil $\mathrm{C}$ processes - notably, the explicit representation of soil microbial activity and metabolic traits (Schmidt et al., 2011; Treseder et al., 2012). Recent research demonstrates that microbial explicit model structures can improve estimates of present-day soil C stocks, and may enhance our ability to predict its response to global change factors (Hararuk et al., 2015; Sulman et al., 2014; Tang and Riley, 2014; Wieder et al., 2013). Yet these models largely ignore metabolic tradeoffs and life-history strategies of microbial communities in soil systems, as well as their interactions with the physicochemical soil environment (Dungait et al., 2012; Miltner et al., 2012; Schimel and Schaeffer, 2012). A functional trait-based approach that broadly captures ecologically relevant niches can simplify microbial metabolic diversity and 
provide a way to examine its role in soil $\mathrm{C}$ dynamics under global change across scales. In terrestrial and marine systems, functional traits provide a tractable means to represent the effects of biodiversity on ecosystem function and biogeochemical cycles across scales (Barton et al., 2013; Reich, 2014), but to date analogous approaches belowground are less well developed.

Resource economic theory provides a framework to understand how tradeoffs in life-history strategies result in growth trait variation among life forms. The theory posits that growth traits develop from the allocation of limited resources to competing metabolic purposes - namely, growth, reproduction, or maintenance functions (Litchman and Klausmeier, 2008). In the ocean, for example, plankton communities are comprised of many functional groups (Barton et al., 2013), where "gleaners" grow slowly and efficiently use and store resources, whereas "opportunists" grow and acquire nutrients quickly though usually have short lifespans (Dutkiewicz et al., 2013; Litchman et al., 2013). The distribution of these functional groups and their diversity helps explain patterns in ocean productivity (Vallina et al., 2014). Similar gradients of trait tradeoffs are observed in terrestrial plants, animals, and aquatic bacteria, described as the "fastslow" plant economic spectrum (Reich, 2014), $r$ - vs. $K$-lifehistory strategies (Pianka, 1970; Sommer, 1981; Wilbur et al., 1974), and copiotrophic vs. oligotrophic growth strategies (Koch, 2001), respectively. Functional groups based on these life-history traits are instrumental in determining the relative abundances of certain organisms in a given environment, influencing the outcome of many ecosystem processes depending on which growth strategy dominates (Follows et al., 2007). Application of functional traits, such as those used to classify plants, provides a tractable means to scale from organismal traits to ecosystem processes and global fluxes (Reichstein et al., 2014; van Bodegom et al., 2014).

A trait-based framework for soil microbes does not yet exist within an ESM. Instead, current representations of microbial diversity in soil models primarily serve to explore microbial community ecology in the context of leaf litter decomposition studies (Allison, 2012; Kaiser et al., 2014) or plant-soil feedbacks (Fontaine and Barot, 2005; Miki et al., 2010). Thus, trait-based microbial explicit models that simulate soil $\mathrm{C}$ stabilization and decomposition are not currently integrated with ecosystem or Earth system models. This is partially the result of inadequate methods to quantify and identify ecologically meaningful traits. However, recent advances in microbial community analyses are creating new opportunities to examine resource controls on the microbial functional trait diversity and abundance (Berg and Smalla, 2009; Fierer et al., 2007, 2012a, b; Krause et al., 2014; Mendes et al., 2014).

In two previously published studies, we documented the feasibility and impact of explicitly representing microbial activity at global scales (Wieder et al., 2013), and introduced MIcrobial-MIneral Carbon Stabilization model (MIMICS)

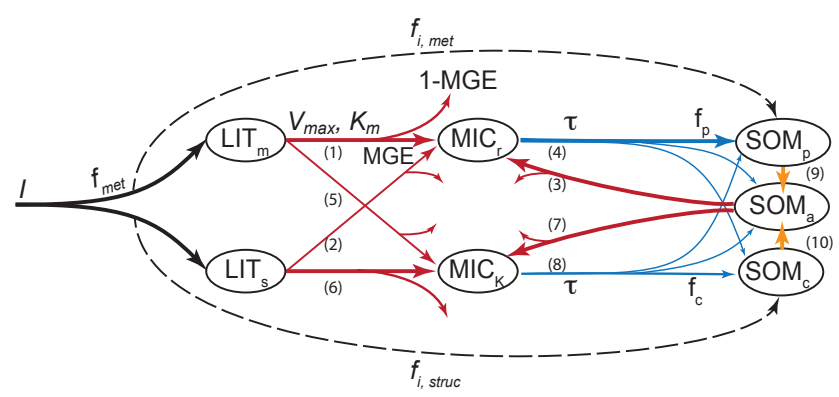

Figure 1. Soil C pools and fluxes represented in MIMICS. Litter inputs $(I)$ are partitioned into metabolic and structural litter pools $\left(\mathrm{LIT}_{\mathrm{m}}\right.$ and $\left.\mathrm{LIT}_{\mathrm{s}}\right)$ based on litter quality $\left(f_{\mathrm{met}}\right)$. Decomposition of litter and available SOM pools $\left(\mathrm{SOM}_{\mathrm{a}}\right)$ are governed by temperature sensitive Michaelis-Menten kinetics $\left(V_{\max }\right.$ and $\left.K_{\mathrm{m}}\right)$, red lines. Microbial growth efficiency (MGE) determines the partitioning of $\mathrm{C}$ fluxes entering microbial biomass pools vs. heterotrophic respiration. Turnover of the microbial biomass ( $\tau$, blue) depends on microbial functional type $\left(\mathrm{MIC}_{\mathrm{r}}\right.$ and $\mathrm{MIC}_{\mathrm{K}}$ ), and is partitioned into available, physically protected, and chemically recalcitrant SOM pools $\left(\mathrm{SOM}_{\mathrm{a}}, \mathrm{SOM}_{\mathrm{p}}\right.$, and $\mathrm{SOM}_{\mathrm{c}}$, respectively). Bracket numbers correspond to the equations for fluxes described in Appendix A1. The definition and values of parameters are included in Table B1.

(Wieder et al., 2014c). Building on this work, in this study we (1) evaluate litter decomposition dynamics with long-term observations across continental-scale climate gradients, extending the analysis from two (Wieder et al., 2014c) to fourteen sites; (2) compare simulated and observed steady-state soil $\mathrm{C}$ pools and simulated soil $\mathrm{C}$ response to nitrogen $(\mathrm{N})$ enrichment; (3) validate global steady-state soil $\mathrm{C}$ projections with observationally derived estimates; and (4) quantify uncertainty in terrestrial $\mathrm{C}$ storage projections with alternative model structures. Our previous efforts to explicitly consider effects of microbial activity at global scales were not similarly validated by cross-site analyses (Wieder et al., 2013). Moreover, simultaneous considerations of litter quality, microbial physiological tradeoffs, and physicochemical protection, key features of MIMICS, were absent from previously published microbial explicit soil biogeochemical models that are run at global scales (Hararuk et al., 2015; Wieder et al., 2013). Moreover, here we explore how MIMICS refines soil $\mathrm{C}$ theory and alters soil $\mathrm{C}$ predictions under global change scenarios, compared to conventional models that do not explicitly account for microbial physiology or functional diversity.

\section{Modeling approach}

MIMICS is a soil $\mathrm{C}$ model that explicitly considers relationships among litter quality, functional tradeoffs in microbial physiology, and the physical protection of microbial byproducts in forming stable soil organic matter (SOM). In MIMICS, microbial biomass pools govern litter and SOM 
turnover and correspond to microbial functional types that exhibit copiotrophic (i.e., $r$-selected) and oligotrophic (i.e., $K$-selected) growth strategies (Fig. 1, Appendix A1). The incorporation of these two groups is a first step towards incorporating microbial functional diversity in a process-based model, which allows us to test recent observations and new theoretical understandings linking microbial functional traits to soil biogeochemical processes (Fierer et al., 2007; Krause et al., 2014; Molenaar et al., 2009). Key functional traits that define microbial growth strategies for copiotrophic and oligotrophic microbial communities include microbial kinetics (based on Michaelis-Menten kinetics; $V_{\max }$ and $K_{\mathrm{m}}$ ), microbial growth efficiency (MGE), and turnover $(\tau)$.

The seven $\mathrm{C}$ pools are considered in MIMICS (Fig. 1) include metabolic and structural litter $\left(\mathrm{LIT}_{\mathrm{m}}\right.$ and $\mathrm{LIT}_{\mathrm{s}}$, respectively); copiotrophic and oligotrophic microbial biomass $\left(\mathrm{MIC}_{\mathrm{r}}\right.$ and $\mathrm{MIC}_{\mathrm{K}}$, respectively); and physically protected, (bio)chemically recalcitrant, and available soil organic matter $\left(\mathrm{SOM}_{\mathrm{p}}, \mathrm{SOM}_{\mathrm{c}}\right.$, and $\mathrm{SOM}_{\mathrm{a}}$, respectively). The chemical quality of plant litter inputs $(I)$ determines partitioning into metabolic and structural litter pools (Parton et al., 1987). The decomposition of LIT and $\mathrm{SOM}_{\mathrm{a}}$ pools follows MichaelisMenten kinetics, with temperature sensitive maximum reaction velocities $\left(V_{\max } ; \operatorname{mg~C}(\mathrm{mg} \mathrm{MIC})^{-1} \mathrm{~h}^{-1}\right)$ and half saturation constants $\left(K_{\mathrm{m}} ; \mathrm{mg} \mathrm{C} \mathrm{cm}^{-3}\right)$ calculated for each substrate and MIC pool (Eqs. 1 and 2):

$$
\begin{gathered}
V_{\max }=e^{(V \text { slope } \times T+V \text { int })} \times a_{\mathrm{v}} \times V_{\text {mod }}, \\
K_{\mathrm{m}}=e^{(K \text { slope } \times T+V \text { int })} \times a_{\mathrm{k}} \times K_{\mathrm{mod}},
\end{gathered}
$$

where $T$ represents mean annual soil temperature (other parameters are described in Table B1). In MIMICS, the physical and biochemical resource environment determines the relative abundance of these microbial functional types. The relative abundance of these functional groups may affect the production and chemical composition of microbial residues that are precursor materials for SOM formation (Grandy and Neff, 2008; Miltner et al., 2012). In contrast to previous work (Wieder et al., 2014c), we have restructured MIMICS here so that microbes only assimilate $\mathrm{C}$ from litter and available $\mathrm{SOM}$ pools. For a full description of model equations and assumptions see Appendix A and Table B1.

\subsection{Cross-site simulations}

To begin evaluating the soil $\mathrm{C}$ dynamics represented in MIMICS, we conducted point simulations at 14 long-term ecological research (LTER) sites that span continental-scale ecoclimatological gradients (Table $\mathrm{C} 1$ ). We examined rates of leaf litter decomposition, steady-state soil C pools, and simulated soil $\mathrm{C}$ responses to $\mathrm{N}$ enrichment.

\subsubsection{Leaf litter decomposition}

First, we parameterized MIMICS with leaf litter decomposition simulations. We compared results to those simulated by
DAYCENT, a well-tested and widely used ecosystem model (Parton et al., 1994; sensu Bonan et al., 2013; Wieder et al., 2014a), and observations of litter mass loss from the Longterm Inter-site Decomposition Experiment Team (LIDET) study (Parton et al., 2007; Adair et al., 2008; Harmon et al., 2009). Expanding on our previous efforts to evaluate soil biogeochemical models with observational data (Bonan et al., 2013; Wieder et al., 2014c), this comparison evaluates the ability of both models to capture climate and litter quality effects on litter decomposition dynamics across continentalscale gradients. Here we summarize important details for the MIMICS simulations.

In contrast to conventional soil biogeochemistry models, MIMICS must first be spun up to steady-state conditions before beginning litter decomposition simulations. To facilitate model parameterization we calculated steady-state $\mathrm{C}$ pools in MIMICS using the stode function in the rootSolve package in R (Soetaert, 2009; R Team, 2014; sensu Wieder et al., $2014 c$ ). This requires site-level information on climate (Harmon, 2013), edaphic properties (Zak et al., 1994), plant productivity (Knapp and Smith, 2001), and plant litter quality - here using biome-level estimates from the TRY plant trait database (Brovkin et al., 2012; sensu Wieder et al., 2014a) (Table C1).

From steady-state conditions we ran parallel simulations with control and experimental simulations. Both simulations were run at hourly time steps, receiving prescribed litter inputs and site-level mean annual temperature; previous work shows no difference between simulations using seasonally varying temperature and mean annual temperature (W. Wieder, unpublished data). Experimental simulations also received additional $100 \mathrm{~g} \mathrm{C}$ to litter pools, portioned according to the lignin: $\mathrm{N}$ ratio of leaf litter used in the LIDET experiment. Substrate and microbial biomass pools sizes determine rates of litter decomposition in MIMICS (Appendix A). Thus, we fixed experimental microbial biomass pool size to those in the control simulations to avoid introducing unintended treatment effects from "litterbag" additions into our analysis (as in Wieder et al., 2014a, b, c). Using the difference between experimental and control litter pools, we calculated the percent mass remaining of six litter types at 14 experimental sites over decade-long simulations. Litter mass loss projections from DAYCENT (results from Bonan et al., 2013) and MIMICS were sampled at the same time points at LIDET results to compare model output with observational data.

\subsubsection{Belowground response to $\mathbf{N}$ enrichment}

Second, we compared projections from both DAYCENT and MIMICS to increasing leaf litter inputs from a simulated $\mathrm{N}$ enrichment. In this analysis we first evaluated the steadystate soil C pool projected by MIMICS and DAYCENT at the 14 LTER sites. DAYCENT represents $C$ turnover aboveand belowground, emphasizing the importance of separately 
considering surface and sub-surface dynamics in soil biogeochemical models (Schmidt et al., 2011). Presently, MIMICS lacks this vertical resolution; thus, we modified the microbial turnover and growth efficiency parameters from those used in the LIDET comparison (and described in Table B1). Parameter modifications used for belowground $\mathrm{C}$ response to $\mathrm{N}$ enrichment are described in Appendix A2, and were necessary to generate steady-state SOC pools that approximated site-level observations (Table C1). The parameter modifications, however, seem justified given uncertainties generated because the processes regulating surface litter turnover differ from the $\mathrm{C}$ stabilization mechanisms that occur in mineral soils (Sollins et al., 1996); explicitly representing these dynamics should be a focus of future model developments. As in leaf litter decomposition simulations (Sect. 2.1.1) litter inputs $\left(\mathrm{g} \mathrm{Cm}^{-2} \mathrm{y}^{-1}\right)$ were distributed throughout the soil profile $(0-30 \mathrm{~cm})$, to calculate volumetric $\mathrm{C}$ pools $\left(\mathrm{mg} \mathrm{C} \mathrm{cm}^{3}\right)$ for MIMICS using the stode function in the rootSolve package in R (Soetaert, 2009; R Team, 2014). Similarly, we used an analytical approach to calculate steady-state pools with DAYCENT, modified to simulate $0-30 \mathrm{~cm}$ depth (Wieder et al., 2014a).

Subsequently, we compared projections from both DAYCENT and MIMICS to increasing leaf litter inputs from a simulated $\mathrm{N}$ enrichment. In a recent meta-analysis, Liu and Greaver (2010) reported that across 111 published N enrichment studies mean leaf litter inputs increased $23 \%$. We used this as the forced response of aboveground net primary productivity (ANPP) in cross-site simulations with both models. Although the temporal dynamics of soil $\mathrm{C}$ responses to environmental perturbations are critical, here we simplify our analysis by focusing on the steady-state response of soil $\mathrm{C}$ stocks to $\mathrm{N}$ enrichment. We calculated the change in steadystate litter, microbial biomass, and soil $\mathrm{C}$ pools in response to this perturbation and compared simulated and observed results. We calculated the response ratio (treatment/control) for both model results and observations, and estimate the $95 \%$ confidence intervals using the boot.ci bootstrap analysis with the boot package in R (Canty and Ripley, 2013). This nonparametric analysis provides a first-order normal approximation of among-site variation in response ratios from observations and models.

Syntheses of $\mathrm{N}$ enrichment studies consistently report declines in microbial biomass (Janssens et al., 2010; Liu and Greaver, 2010; Lu et al., 2011). We hypothesized these observations could guide the parameterization of potential microbial response to $\mathrm{N}$ enrichment; nevertheless, as this study focuses on C-only models, our interest in these particular simulations was largely theoretical. Thus, our analyses of belowground $\mathrm{C}$ response to simulated $\mathrm{N}$ enrichment were intended to explore the parameter modifications that would have to be made for models to replicate these observations.

DAYCENT does not simulate microbial biomass pools, and the modifications that would be necessary to match observational data could include faster turnover of SOM pools (van Groenigen et al., 2014) and/or decreased MGE (Frey et al., 2013). Both of these modifications contradict current empirical and theoretical understanding of soil microbial responses to $\mathrm{N}$ enrichment (Janssens et al., 2010; Manzoni et al., 2012); thus, we made no changes to DAYCENT parameterizations.

Without modifications preliminary results indicated that MIMICS underestimated litter $\mathrm{C}$ accumulation and built excessive amounts of microbial biomass. Observed declines in microbial biomass could be replicated with MIMICS if $\mathrm{N}$ enrichment modified microbial physiology and the competitive interactions between oligotrophic and copiotrophic functional groups. Moreover, several papers document shifts in the relative abundance of copiotrophic bacteria in response to $\mathrm{N}$ enrichment (Fierer et al., 2012a; Ramirez et al., 2012). Thus, we ask what changes in microbial physiology could alter the competitive dynamics between microbial functional groups in MIMICS to simultaneously increase the relative abundance of copiotrophs, reduce total microbial biomass, and replicate observed litter and soil $\mathrm{C}$ responses?

Several microbial physiological responses may elicit these change in MIMICS, they include increased growth efficiency (MGE), direct enzyme inhibition (reducing $V_{\max }$ ), and changes in microbial turnover $(\tau)$. We investigated the each mechanism, by individually perturbing single variables and quantifying effects on C pools in MIMICS. These analyses were intended to demonstrate the general applicability of MIMICS to both evaluate and generate testable hypotheses that may provide greater insight into soil biogeochemical dynamics. The exercise also may help focus efforts to develop empirical functions that describe microbial physiological response to environmental change. In the first scenario, we assume inherent physiological traits of the copiotrophic microbial community generate greater $\mathrm{N}$ demands and a lower microbial $\mathrm{C}: \mathrm{N}$ ratio relative to their oligotrophic counterparts (Kaiser et al., 2014). As N enrichment may alleviate this $\mathrm{N}$ limitation, we increase the MGE of the copiotrophic community. In a second scenario, we represent $\mathrm{N}$ inhibition of oxidative enzyme activity (Fog, 1988; Knorr et al., 2005) by decreasing the $V_{\max }$ parameter associated with oligotrophic community decomposition. Finally, experimental warming has been shown to increase the turnover (but not efficiency) of microbial communities (Hagerty et al., 2014). Although to our knowledge there is no direct evidence for this response following $\mathrm{N}$ enrichment, we explore the feasibility of changes in microbial turnover to explain observed belowground $\mathrm{C}$ response to $\mathrm{N}$ enrichment. Specific changes to individual parameters are described in Appendix A2.

\subsection{Global simulations}

First, we compared the steady-state soil C stocks from MIMICS to field-derived soil $\mathrm{C}$ distributions, and then examined the response of soil $\mathrm{C}$ storage to increasing litter inputs from rising $\mathrm{CO}_{2}$ over the 21 st century. 

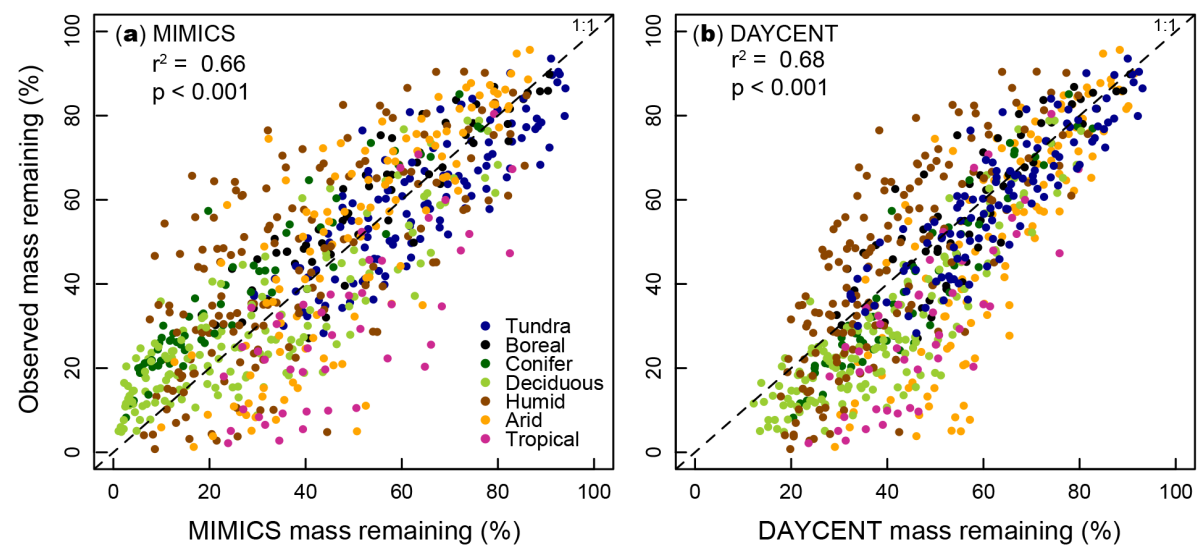

Figure 2. Litter decomposition results from observation and models. Points show the percent leaf litter mass remaining of six different litter types that decomposed over a decade-long experiment across 14 different LTER sites, which correspond to seven different biomes. Simulations from (a) MIMICS and (b) DAYCENT were sampled at the same time points as LIDET observations. Dashed line shows the $1: 1$ line (see also Table 1).

\subsubsection{Global steady-state soil C estimates}

Steady-state soil C estimates from MIMICS were generated using globally gridded estimates of mean annual net primary productivity (NPP) and soil temperature from an offline simulation of the Community Land Model, version 4.5 (CLM4.5) (D. Lawrence and C. Koven, unpublished data) as well as soil texture from the Harmonized World Soils Database (FAO et al., 2012) and litter quality (Brovkin et al., 2012) that were modified to the CLM grid (Wieder et al., 2014a, b). Using the stode function in the R rootSolve package (Soetaert, 2009) we calculated steady-state litter, microbial biomass, and soil C pools in MIMICS. In applying MIMICS at global scales and to a depth of $1 \mathrm{~m}$ we adjusted parameter values $\tau, f_{\text {met }}, f_{\mathrm{c}}$, and $P_{\text {scalar }}$ (Appendix A3). All other parameter values were the same as in the LIDET experiment (Table B1). We compared soil C pools simulated by CLM4.5 and MIMICS (both $0-100 \mathrm{~cm}$ ) to observationally derived soil $\mathrm{C}$ estimates reported in the Harmonized World Soils Database (FAO et al., 2012) for the same depth interval (Wieder et al., 2014a, b, 2013).

\subsubsection{Global response to changing litter inputs}

Subsequently, we compared soil C projections from CLM4.5 and MIMICS to changing litter inputs under a simulation with elevated $\left[\mathrm{CO}_{2}\right]$ and constant climate. Mean annual NPP and soil temperature from CLM4.5 simulations were similarly used to force MIMICS. We did not modify our parameterization of MIMICS in transient global simulations because we lack the process-level understanding to guide potential microbial responses to elevated $\left[\mathrm{CO}_{2}\right]$. Instead, our aim was to illustrate the potential effects of applying a microbial explicit approach in global $\mathrm{C}$ cycle projections. In our simulations we assume increases in $\left[\mathrm{CO}_{2}\right]$ under Representative Concentration Pathway (RCP) 8.5 from 2006 to 2100 with a constant climate scenario (1850-1870), thus isolating the effects of increased productivity on soil $\mathrm{C}$ storage. We calculated the change in soil C pools simulated by CLM4.5 and MIMICS over the 21 st century; however, differences in soil C accumulation between the models are likely conservative estimates because of discrepancies in how $\mathrm{C}$ substrates entered soil pools. The absolute $\mathrm{C}$ fluxes in MIMICS simulations are greater than CLM4.5, because we assume that changes in NPP immediately produce litterfall fluxes that enter LIT and SOM pools represented in MIMICS. Soils in CLM4.5 experience a longer temporal lag when "new" NPP enters litter pools, especially in forested regions where increasing NPP builds woodier biomass and augments coarse woody debris pools. These wood pools must first decompose before $\mathrm{C}$ substrates enter litter, and eventually SOM pools.

\section{Results}

\subsection{Cross-site simulations}

\subsubsection{Leaf litter decomposition}

MIMICS and DAYCENT both reproduce climate effects on mean rates of litter mass loss among sites. Both models also replicate within site variation driven by litter quality $\left(r^{2}=\right.$ 0.66 and 0.68 , respectively, $p<0.001$; Fig. 2 , Table 1 ). Notably, the greater process-level representation provided with MIMICS does not degrade projections, compared with results from a microbial implicit model, or simpler statistical models (Adair et al., 2008). We also recognize that more challenges lie ahead (Davidson et al., 2014), as additional environmental controls are relevant in governing rates of litter and SOM decomposition and stabilization. 
Table 1. Biome-aggregated results for leaf litter decomposition experiment that compares simulations from MIMICS and DAYCENT with observations from the LIDET study (Fig. 2). Models were sampled at the same time as observations for each litter type decomposed at each site. Data show the number of observations $(n)$, Pearson's correlation coefficient $(r)$, root mean square error (RMSE), and bias calculated between observed and simulated percent mass remaining. Sites grouped into each biome include tundra (ARC and NWT); boreal forest (BNZ); conifer forest (AND); deciduous forests (CWT, HBR and HFR); humid grasslands (CDR, KBS, and KNZ); arid grasslands (JRN, SEV, SGS); and tropical forest (LUQ; Table B1 for site abbreviations).

\begin{tabular}{|c|c|c|c|c|c|c|c|}
\hline \multirow[b]{2}{*}{ Biome } & \multirow[b]{2}{*}{$n$} & \multicolumn{3}{|c|}{ MIMICS } & \multicolumn{3}{|c|}{ DAYCENT } \\
\hline & & $r$ & RMSE & bias & $r$ & RMSE & bias \\
\hline Tundra & 114 & 0.84 & 10.0 & 3.8 & 0.88 & 8.3 & 3.2 \\
\hline Boreal forest & 60 & 0.91 & 9.2 & -4.5 & 0.86 & 9.1 & -0.6 \\
\hline Conifer Forest & 60 & 0.95 & 13.2 & -11.6 & 0.94 & 9.1 & 5.9 \\
\hline Deciduous forests & 148 & 0.86 & 11.1 & -0.7 & 0.87 & 13.6 & 10.5 \\
\hline Humid grasslands & 151 & 0.70 & 18.8 & -7.3 & 0.78 & 15.2 & -4.2 \\
\hline Arid grasslands & 113 & 0.83 & 15.2 & -0.4 & 0.82 & 19.9 & 11.6 \\
\hline Tropical forest & 46 & 0.74 & 21.7 & 17.2 & 0.80 & 20.8 & 17.0 \\
\hline All & 692 & 0.81 & 14.56 & -1.42 & 0.82 & 14.5 & 5.4 \\
\hline
\end{tabular}

\subsubsection{Belowground response to $\mathrm{N}$ enrichment}

Both MIMICS and DAYCENT can capture the ecoclimatological effects and continental-scale variation in steady-state soil C pools among the 14 LTER sites studied here (Pearson's correlation $r=0.77$ and $0.47, P=0.001$ and 0.09 , respectively; Table $\mathrm{C} 1$ ). This indicates that the parameterizations of both models can replicate continentalscale variation in litter decomposition and soil $\mathrm{C}$ storage; thus, we examined soil $\mathrm{C}$ projections from MIMICS and DAYCENT and contrast their potential response to environmental perturbations.

From these steady-state conditions, we considered the potential soil $\mathrm{C}$ storage response to $\mathrm{N}$ enrichment. While $\mathrm{N}$ enrichment may drive increases in plant productivity, metaanalyses consistently demonstrate that $\mathrm{N}$ fertilization studies result in declining microbial biomass pools and modest to negligible changes in soil $\mathrm{C}$ storage (Fig. 3, open circles) (Janssens et al., 2010; Liu and Greaver, 2010; Lu et al., 2011). In first-order models steady-state litter and SOM pools are directly proportional to litterfall inputs. Consequently, steady-state litter and SOM pools simulated by DAYCENT increased in excess of observations (Fig. 3, filled squares).

Greater mechanistic representation in MIMICS may shed light into how microbial physiology may respond to perturbations, and how those physiological change may influences soil C storage. Without modifications MIMICS underestimates litter $\mathrm{C}$ accumulation and builds excessive amounts of microbial biomass, but projects reasonable changes in soil $\mathrm{C}$ pools in response to increasing litter inputs (Fig. 3, open triangles).

In our first scenario, increasing the MGE of the copiotrophic community increased their relative abundance, summarized by the copiotrophic: oligotrophic $(\mathrm{C}: \mathrm{O})$ ratio,

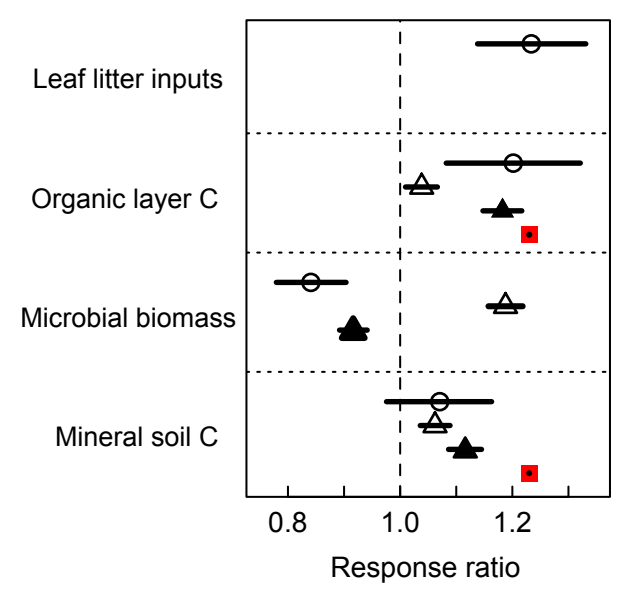

Figure 3. Observed and modeled $\mathrm{C}$ response ratio (treatment/control) to experimental $\mathrm{N}$ enrichment. Open circles show observed mean and $95 \%$ confidence interval of leaf litter inputs, organic layer C, microbial biomass, and mineral soil C (Liu and Greaver, 2010). Modeled results show the steady-state changes in pools following increases in leaf litter inputs projected by MIMICS (open triangles), MIMICS (with increasing MGE in response to $\mathrm{N}$ enrichment; filled triangles) and DAYCENT (filled squares; see also Supplementary Fig. 1).

which increased from $12.6 \pm 3.2$ (mean $\pm 1 \sigma$ ) to $39.6 \pm 8.8 \%$ following modifications to MGE parameters. Because the copiotrophic microbes have higher turnover rates, an increase in their relative abundance accelerated communityaggregated rates of turnover and decreased total microbial biomass (Fig. 3, filled triangles). Concurrent changes in steady-state litter and SOM pools fall within observational uncertainty bounds.

In our second scenario, modifying kinetics parameters produced reasonable agreement with observed steady-state 
litter and SOM pools, but simulated changes in microbial biomass pools are still well outside the range of observations (Supplementary Fig. 1a). Modifying microbial kinetics generally elicited less dramatic shifts in the relative abundance of microbial functional types than MGE modifications, altering the mean $\mathrm{C}: \mathrm{O}$ ratio from $34.8 \pm 8.6 \%$ to $37.1 \pm 9.9 \%$. More drastic changes to other microbial kinetics parameters (e.g., concurrently increasing the $V_{\max }$ of copiotrophic-controlled fluxes), generated larger shifts in the $\mathrm{C}: \mathrm{O}$ ratio and better matched observed microbial biomass responses, but also compromised model agreement with observed changes to litter and SOM pools (data not shown).

In our third scenario, accelerating microbial turnover directly decreases the size of microbial biomass pools, but increases inputs of microbial residues that build stable SOM (Wieder et al., 2014c). Smaller microbial biomass pools also slow rates of litter decomposition. Thus, increasing turnover rates of both microbial functional types cannot drive large enough changes in microbial biomass pools without exceeding observational bounds for litter and SOM pools (data not shown). Shifting towards a more copiotrophic-dominated community by modifying microbial turnover elicits similar responses as in MGE modifications, but with greater accumulation of litter and soil C (Supplementary Fig. 1b).

\subsection{Global simulations}

\subsubsection{Steady-state soil C estimates}

Mean global NPP simulated by CLM4.5 totaled 50.1 \pm $1.0 \mathrm{PgC}^{-1}$ at the end of the historical period (1996-2005). Given these inputs, litter and SOM pools $(0-100 \mathrm{~cm})$ simulated by CLM4.5 totaled 66 and $1780 \mathrm{PgC}$, respectively. Results that show moderately strong agreement with observationally derived estimates of soil C stocks from the Harmonized World Soils Database (Fig. 4a, b), with a stronger spatial correlation $(r=0.42)$ and comparable root mean square error (RMSE) $\left(13.7 \mathrm{~kg} \mathrm{Cm}^{-2}\right)$ as the fully coupled ESMs represented in the Coupled Model Intercomparison Project, phase 5 (CMIP5) archive (Todd-Brown et al., 2013). Using the same NPP and mean annual soil temperature, steady-state litter, microbial biomass, and SOM pools simulated by MIMICS totaled 218, 16.3, and $1530 \mathrm{PgC}$, respectively (Fig. 4c). MIMICS SOM estimates show a higher spatial correlation with the Harmonized World Soils Database $(r=0.46)$ and have a smaller RMSE $\left(6.8 \mathrm{~kg} \mathrm{Cm}^{-2}\right)$ than the CLM4.5 results shown here, the CLM microbial model (Wieder et al., 2013) forced with the same data (W. Wieder, unpublished data), or any of the models represented in the CMIP5 archive (Todd-Brown et al., 2013).

Steady-state litter pool estimates from MIMICS are inversely related to mean annual soil temperature $(r=-0.89)$, and largest in high latitude systems. Given its slower turnover, structural litter pools made up the bulk of total litter pools $(79 \pm 4.6 \%)$ and show a fairly even spatial dis-

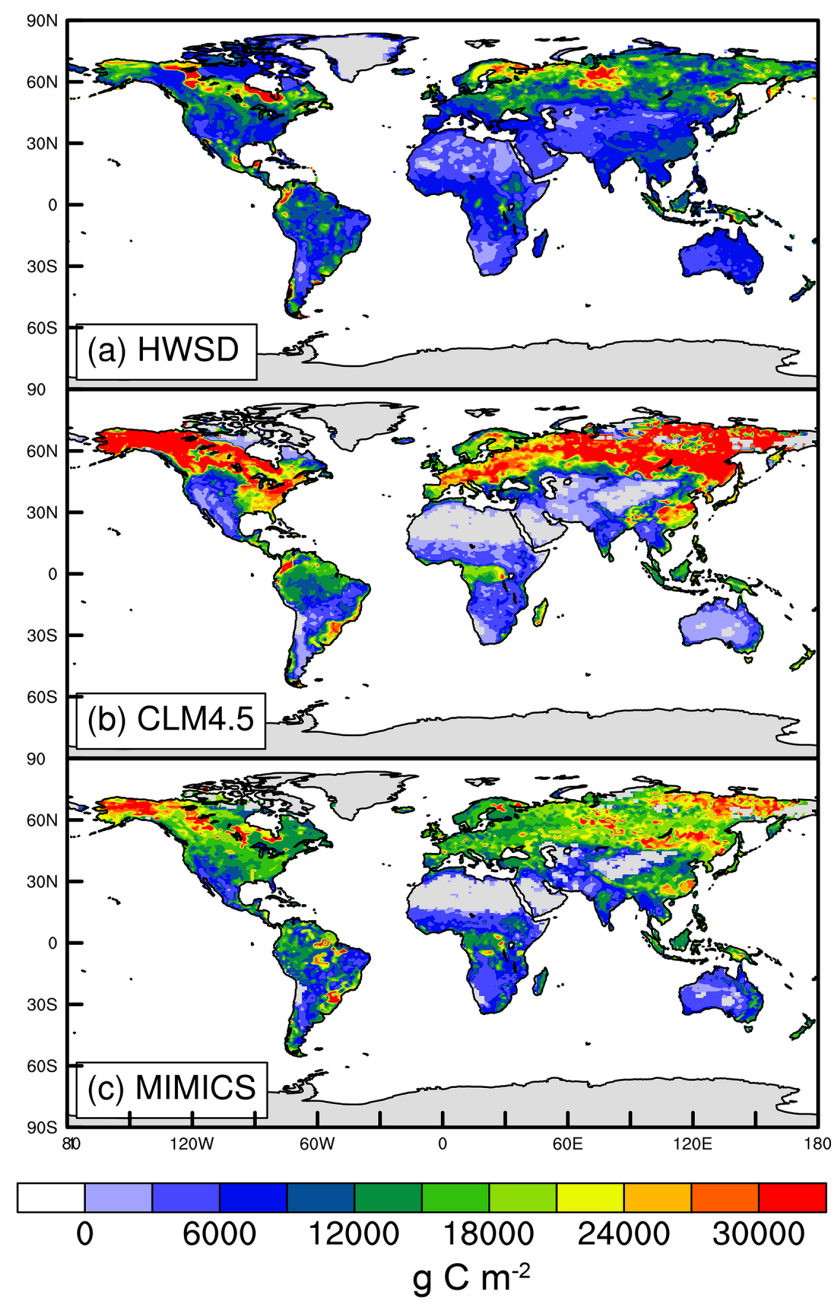

Figure 4. Global soil $\mathrm{C}$ pools $\left(\mathrm{g} \mathrm{C} \mathrm{m}^{-2}, 0-100 \mathrm{~cm}\right)$ from observations and models. (a) Observations from the Harmonized World Soils Database and global total $=1260 \mathrm{PgC}$. (b) CLM4.5 global total $=1780 \mathrm{PgC}$ (spatial correlation with observations $(r)=0.42$, model-weighted root mean square error $(\mathrm{RMSE})=13.7 \mathrm{~kg} \mathrm{Cm}^{-2}$ ). (c) MIMICS global total $=1530 \mathrm{PgC}$ $\left(r=0.46, \mathrm{RMSE}=6.8 \mathrm{~kg} \mathrm{Cm}^{-2}\right)$.

tribution (Supplementary Fig. 2a). Estimates of microbial biomass from MIMICS were strongly related to NPP estimates $(r=0.99)$, in accordance with observations (Bradford et al., 2013; Fierer et al., 2009). The C : O ratio in soils was $0.46 \pm 0.13$, and was positively correlated with the chemical quality of litter inputs ( $r=0.80$; Supplementary Fig. 2b). Physically protected SOM comprised $15 \pm 15 \%$ of total SOM pools; but in clay-rich soils, especially across the tropics, over half of total soil $\mathrm{C}$ was found in physically protected pools (Supplementary Fig. 2c). Chemically recalcitrant and available SOM comprised $28 \pm 10 \%$ and $57 \pm 12 \%$ of total SOM pools, respectively, and were generally higher in high latitude ecosystems (Supplementary Figs. 2d, e). Finally, total microbial biomass pools comprise $2.5 \pm 9.6 \%$ of total 

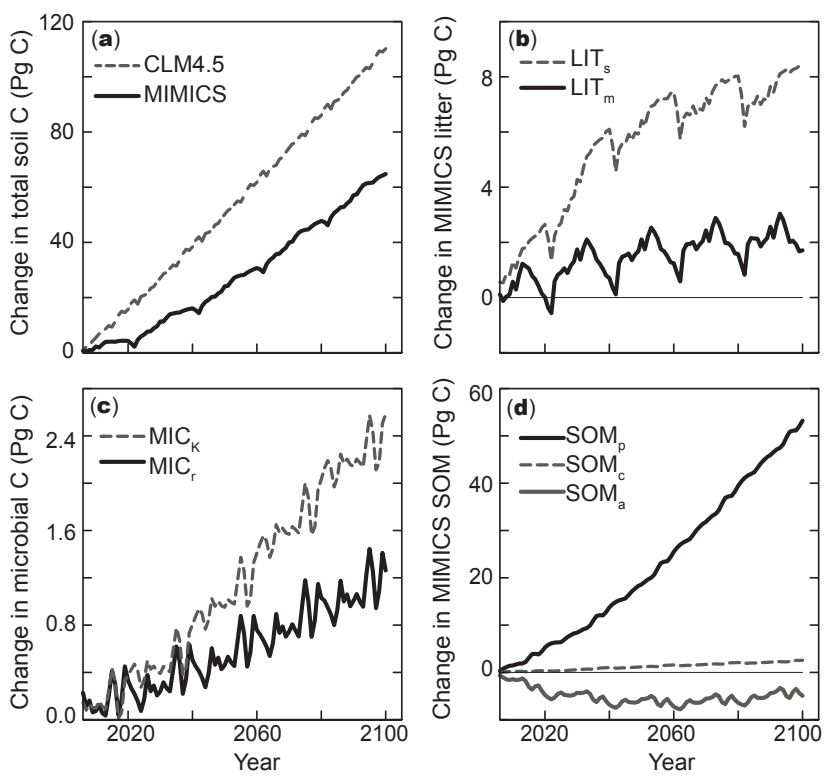

Figure 5. Temporal change in global soil C pools (Pg C; $0-100 \mathrm{~cm})$ in response to elevated $\left[\mathrm{CO}_{2}\right]$ and increasing plant productivity throughout the $21 \mathrm{st}$ century. (a) Changes in all litter, microbial biomass, and SOM pools simulated by CLM4.5 (dashed line) and MIMICS (black line), totaling 110 and $65 \mathrm{PgC}$ globally, respectively, for simulations receiving the same $\mathrm{C}$ inputs and environmental conditions. Specific changes in individual MIMICS pools included (b) Structural and metabolic litter pools (dashed and solid lines, respectively); (c) Oligotrophic and copiotrophic soil microbial biomass pools (dashed and solid lines, respectively); and (d) physically protected, chemically recalcitrant, and available SOM pools (solid black, dashed, and solid grey lines, respectively). Results are from offline (land-only), biogeochemically coupled simulations where terrestrial NPP increases from $50 \mathrm{PgCy}^{-1}$ in 2005 to $64 \mathrm{PgC}^{-1}$ by 2100 , without concurrent changes in climate. Note differences in the $y$ axes scales among panels.

SOM pools, within observational bounds (Serna-Chavez et al., 2013; Xu et al., 2013), although this high variability is largely driven by the $2 \%$ of grid cell around desert regions that have significantly higher microbial biomass : SOM ratios (Supplementary Fig. 2f).

\subsubsection{Response to changing litter inputs}

Elevated $\left[\mathrm{CO}_{2}\right]$ increases global NPP estimates from CLM4.5 $27 \%$ percent over 2005 levels, totaling 63.6 $\mathrm{PgCy}^{-1}$ by 2100. Global litter and SOM pools in CLM4.5 increase linearly throughout the 21 st century, gaining 22 and $88 \mathrm{PgC}$, respectively, by 2100 , resulting in $110 \mathrm{PgC}$ of terrestrial C storage in the top meter of soils (Fig. 5a). MIMICS projects less optimistic gains in soil $\mathrm{C}$ storage with increased terrestrial productivity: global litter, microbial biomass, and SOM pools simulated by MIMICS increased 10, 3.8, $51 \mathrm{PgC}$, respectively, with terrestrial soil $\mathrm{C}$ storage increasing $65 \mathrm{PgC}$ by the end of the 21 st century.

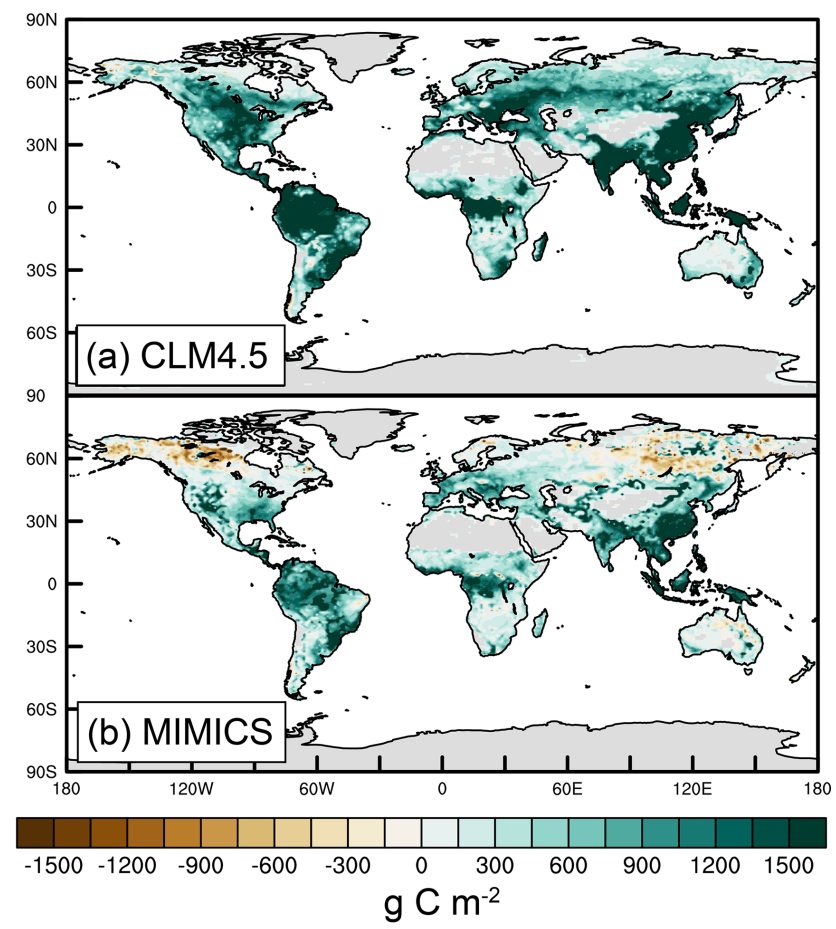

Figure 6. Spatial distribution of changes in soil $\mathrm{C}$ pools projected using (a) CLM4.5 and (b) MIMICS. Values $\left(\mathrm{g} \mathrm{Cm}^{-2}\right)$ were calculated by subtracting the sum of all soil $\mathrm{C}$ pools $(0-100 \mathrm{~cm})$ projected in 2100 under RCP $8.5\left[\mathrm{CO}_{2}\right]$ from those estimated in 2005. Positive values show regions of net soil $\mathrm{C}$ accumulation over the $21 \mathrm{st}$ century with increasing litter inputs from elevated $\left[\mathrm{CO}_{2}\right]$.

Thus, with the same experimental forcing, total soil C changes projected by MIMICS are nearly half of those from CLM4.5. With MIMICS, litter and microbial biomass pools clearly respond to inter-annual variation in soil temperature (Fig. 5), although the magnitude of this variation is less than two percent of global pools. We suspect the irregular oscillation and regular periodicity observed in Fig. $5 \mathrm{~b}$ results from the anomaly forcing protocol used to generate the biogeochemically coupled RCP8.5 results in the CLM4.5 simulation that were also used in MIMICS simulations. We note, that further study is needed to investigate how the timing and magnitude of litter inputs and temperature variation effects soil C projections in MIMICS. Litter, microbial biomass, and physically protected SOM pools demonstrate a linear increase with increasing NPP throughout the 21st century, similar to the CLM4.5 response.

The spatial distribution of soil $\mathrm{C}$ changes projected by CLM4.5 and MIMICS in response to increasing NPP strongly diverge (Fig. 6). Total soil $\mathrm{C}$ gains projected by CLM4.5 are large across the vegetated land surface, and positively correlated with NPP $(r=0.61)$. By contrast, MIMICS projects more modest soil $\mathrm{C}$ gains that are largely driven by $\mathrm{C}$ accumulation in physically protected $\mathrm{SOM}$ pools $(53 \mathrm{Pg}$ globally by 2100) concentrated in tropical and mid-latitude 
ecosystems (Fig. 6 and Supplementary Fig. 3). MIMICS also projects small increases in chemically recalcitrant SOM pools $(2.3 \mathrm{Pg})$, and modest $\mathrm{C}$ losses from available SOM pools $(-5.0 \mathrm{Pg}$, globally by 2100$)$, with the greatest declines in high latitude systems. We stress, these patterns result from a consistent parameterization applied across global simulations (described in Sect. 2.2 and Table B1, with parameter modifications detailed Appendix A3). Results presented here emerge from the biogeographical differences in litter quality, soil texture, and their interactions via microbial community composition.

\section{Discussion}

The incorporation of microbial functional diversity in MIMICS enhanced both the prediction and understanding of potential feedbacks between microbial traits and soil $\mathrm{C}$ cycle dynamics, relative to models that lack explicit representation of microbial diversity such as DAYCENT or CLM. Though we already know that conventional and microbial models provide divergent predictions of soil $\mathrm{C}$ dynamics in transient simulations (Wieder et al., 2013), previous models used to predict $\mathrm{C}$ cycle-climate feedbacks fail to represent the metabolic tradeoffs within microbial communities, physiological traits, or interactions with the physicochemical environment. Such deficiencies limit their capacity to inform our theoretical and mechanistic understanding of how soil microbial activity and diversity may ultimately affect soil $\mathrm{C}$ storage (Perveen et al., 2014) under various global perturbations. Using a trait-based model structure, MIMICS enhances both prediction and understanding of feedbacks between microbial diversity and soil biogeochemical function.

\subsection{Cross-site simulations}

The absolute and relative abundance of microbial functional types strongly regulates rates of $\mathrm{C}$ turnover in MIMICS. At sites spanning continental-scale gradients, MIMICS and DAYCENT can both replicate observations from the LIDET study (Fig. 2, Tables 1, C1), providing robust validation for climate and litter quality effects on simulated rates of leaf litter decomposition. By applying contemporary understanding of soil biogeochemical theory, particularly the inclusion of different microbial communities, MIMICS also generates a host of testable hypotheses that can motivate synergistic data collection - model development activities. Specifically, MIMICS responds more accurately to regional-scale perturbations, as illustrated by the cross-site response to $\mathrm{N}$ enrichment.

Potential effects of $\mathrm{N}$ enrichment on soil microbial activity, microbial community composition, and biogeochemical responses illustrate one example where such synergy may be found. Nitrogen enrichment commonly depresses oxidative enzyme activity (Saiya-Cork et al., 2002; Waldrop et al.,
2004) and shifts microbial community structure (Fierer et al., 2012a; Frey et al., 2004; Gallo et al., 2004; Ramirez et al., 2012). As a result, $\mathrm{N}$ enrichment typically decreases rates of leaf litter decomposition (Fog, 1988; Hobbie, 2008; Knorr et al., 2005), reduces total microbial biomass pools and results in modest to negligible changes in soil C storage (Janssens et al., 2010; Liu and Greaver, 2010; Lu et al., 2011). These responses present significant modeling challenges because, as commonly parameterized, the quantity of litter inputs are proportional to the size of SOM and microbial biomass pools in conventional and microbial explicit models, respectively (Todd-Brown et al., 2013; Wang et al., 2014; Wieder et al., 2013). First-order models could match these observations, through accelerated turnover or increased heterotrophic respiration rates following $\mathrm{N}$ enrichment. Such modifications, however, provide no additional insight into potential mechanisms that may be responsible for observed soil $\mathrm{C}$ responses to $\mathrm{N}$ enrichment. Moreover, they may actually contradict theoretical understanding of the microbial physiological response to increased nutrient availability (e.g., Knorr et al., 2005; Manzoni et al., 2012).

By considering the physiological attributes of microbial functional types, MIMICS provides a means to capture the nuanced changes in inputs, microbial biomass, and soil $\mathrm{C}$ following $\mathrm{N}$ enrichment. Theory and observations suggest that MGE should increase with nutrient availability, although data are sparse from soil systems (Manzoni et al., 2012). Theoretically, $\mathrm{N}$ enrichment may increase the MGE of the copiotrophic microbial community by decreasing the energy spilling (Bradford, 2013) associated with their intrinsically high $\mathrm{N}$ demand (Kaiser et al., 2014). By increasing copiotrophic growth efficiency with $\mathrm{N}$ enrichment, this community builds more biomass, better competes for $\mathrm{C}$ substrates, and increases in relative abundance; results that are consistent with observational findings from $\mathrm{N}$ enrichment manipulations (Fierer et al., 2012a; Ramirez et al., 2012). Thus, microbial community shifts driven by changes in MGE may provide a mechanism that explains soil biogeochemical responses to N enrichment (Fig. 3) (Chen et al., 2014). Assuming the oligotrophic community produces more oxidative enzymes, decreasing their absolute abundance would elicit declines in oxidative enzyme activity (Saiya-Cork et al., 2002; Waldrop et al., 2004). Our results suggest this is more likely through changes in community structure that are driven by MGE or microbial turnover than through direct enzyme inhibition (Supplementary Fig. 1a). These examples broadly illustrate how consideration of microbial functional traits in MIMICS can simultaneously advance predictions and theory, producing testable hypotheses that can help guide future experimental work.

The interplay between microbial community composition and soil biogeochemical response in MIMICS depends on assumptions made about how physiological differences between microbial functional types affect the ultimate fate of C (Schimel and Schaeffer, 2012; Wieder et al., 2014c). 
However, microbial allocation strategies remain poorly understood, emphasizing the need for better theoretical and quantitative understanding microbial physiological traits, including microbial efficiency and turnover (Hagerty et al., 2014), the partitioning of microbial residues into different SOM pools, and microbial $\mathrm{C}: \mathrm{O}$ ratios. Moreover, we also lack adequate data and understanding of how microbial physiological traits and microbial communities may be shaped by environmental gradients or respond to perturbations (Fierer et al., 2012b). Currently, litter chemical quality determines the relative abundance of microbial functional groups in MIMICS, but variation in factors such as soil moisture, temperature, $\mathrm{pH}$, and the frequency of litter inputs likely influence microbial community composition (Berg and Smalla, 2009; Fierer et al., 2012b). Addressing these limitations across sites that span key eco-climatological gradients will improve our theoretical understanding and numerical representation of soil processes in MIMICS and other microbial models.

\subsection{Global simulations}

The temporal and spatial responses of MIMICS to increasing NPP illustrate model characteristics that have important implications in understanding potential $\mathrm{C}$ cycle-climate feedbacks. Observations across $\mathrm{CO}_{2}$ enrichment studies show muted soil $\mathrm{C}$ accumulation with increasing plant productivity (Hungate et al., 2009). In models, this response can be simulated by accelerating rates of SOM turnover with increasing $\mathrm{C}$ inputs; a process that has to be separately parameterized in conventional soil C models (van Groenigen et al., 2014), but which is an emergent property of MIMICS. With identical forcings, MIMICS projects significantly less soil $\mathrm{C}$ accumulation than CLM4.5 (Figs. 5, 6), suggesting that application of microbial explicit soil biogeochemistry models in ESMs may significantly reduce projected terrestrial concentrationcarbon feedbacks.

Concentration-carbon feedbacks, or the land $\mathrm{C}$ response to elevated $\left[\mathrm{CO}_{2}\right]$, represents one of the strongest, but most uncertain features of terrestrial $\mathrm{C}$ projections from the CMIP5 model archive (Arora et al., 2013). Across models, the terrestrial response to elevated $\left[\mathrm{CO}_{2}\right]$ depends on changes in plant productivity and the long-term stabilization of that $\mathrm{C}$ in soils. Conventional soil $\mathrm{C}$ models emphasize the stabilization of additional $\mathrm{C}$ inputs and show significant increases in soil C storage in response to increasing NPP (Todd-Brown et al., 2014; Wieder et al., 2013) (Fig. 5). By contrast, microbial explicit models often emphasize priming and accelerated soil $\mathrm{C}$ mineralization with increasing productivity, thus showing no long-term soil C accumulation (Wang et al., 2014; Wieder et al., 2013). Results from MIMICS present a middle ground between these two approaches, where increasing litter inputs accelerates rates of soil $\mathrm{C}$ turnover, but also builds stable SOM (Figs. 5, 6). These findings result from the implementa- tion of microbial traits and their interactions with the physicochemical soil environment in MIMICS.

Strikingly different spatial patterns of soil C changes emerge from our global simulations. Whereas CLM4.5 presents nearly uniform increases in soil $\mathrm{C}$ accumulation across vegetated land surfaces, MIMICS projects a much more nuanced and heterogeneous response of soil $\mathrm{C}$ response to increasing NPP (Fig. 6). Low-latitude and some temperate ecosystems provide a moderate $\mathrm{C}$ sink, while high latitude systems become a week source of $\mathrm{C}$ to the atmosphere. These spatial differences are driven by the response of microbial biomass and SOM pools to increasing litter inputs in MIMICS. Globally, increasing litter inputs builds more microbial biomass (Fig. 5). Subsequent effects of larger microbial biomass pools on soil C storage, or loss, depend on interactions between microbial functional traits, community composition, and the physicochemical soil environment.

Microbial residues build SOM, especially in clay-rich soils that physically protect inherently labile microbial residues. At low latitudes the high chemical quality of litter inputs increases the relative abundance of copiotrophs, which also have faster turnover rates and produce residues that are physically protected in clay-rich soils common across the tropics (Supplementary Fig. 2d). Accordingly, we see the largest soil $\mathrm{C}$ gains in physically protected SOM pools across the tropics in response to elevated $\left[\mathrm{CO}_{2}\right]$ (Figs. $6 \mathrm{~b}$ and Supplementary Fig. 3a), illustrating how interactions between microbial functional traits and the physicochemical soil environment may influence soil $\mathrm{C}$ responses to perturbations. By contrast, low litter quality characteristic in high latitude systems favors an oligotrophic-dominated community. The coarsely textured soils common at high latitudes also afford little physical protection of SOM. These factors result in large SOM pools that are not protected by mineral-association and are vulnerable to microbial degradation and loss. Thus, increasing NPP and microbial biomass accelerates the decomposition of litter and SOM, with significant losses from available SOM pools evident across arctic and boreal ecosystems (Figs. 6b and Supplementary Fig. 3c). By incorporating a trait-based framework, spatial variability in soil $\mathrm{C}$ projections from MIMICS generate testable hypotheses that can be evaluated with future experimental work. These results emphasize the importance of interactions between litter quality, microbial community dynamics, and soil texture in mediating soil $\mathrm{C}$ response to environmental change at regional to global scales.

Although direct experimental tests to evaluate these results are scant, results from leaf litter manipulations indicate that augmenting litter $\mathrm{C}$ inputs may drive soil $\mathrm{C}$ accumulation on high-clay soils (e.g., tropical forests; Leff et al., 2012; cf. Sayer et al., 2011), whereas coarsely textured soils (e.g., temperate forests) show less dramatic soil C accumulation, and some evidence for net soil $\mathrm{C}$ losses (Bowden et al., 2014; Lajtha et al., 2014). Moreover, empirical data shows $\mathrm{CO}_{2}$ enrichment may stimulate plant productiv- 
ity, but without proportional increases in soil C storage (Hungate et al., 2009; van Groenigen et al., 2014). Thus, we find little experimental evidence to support the large and ubiquitous soil $\mathrm{C}$ gains projected by CLM4.5 and other conventional soil biogeochemistry models in response to increasing $\mathrm{C}$ inputs. Although projections from MIMICS seem to better agree with observations, greater attention should be given to evaluating the models' process-level representation and temporal dynamics across eco-climatological gradients. Key uncertainties in the parameterization of MIMICS include the partitioning of microbial residues to different SOM pools as well as understanding factors controlling $\mathrm{C}$ fluxes between protected and available pools. In particular, these fluxes are critical in regulating the size and turnover of physically protected SOM pools in MIMICS, which largely determine the soil C response (Figs. 5, 6 and Supplementary Fig. 3).

Beyond differences in total soil $\mathrm{C}$ accumulation, MIMICS also shows stronger sensitivity to inter-annual variability than conventional models. For example, effects of inter-annual temperature variability on litter and microbial biomass pools are clearly evident (Fig. 5). Following perturbations, microbial explicit models can also exhibit an oscillatory behavior (Li et al., 2014; Wang et al., 2014). Our global simulation provides some insight into the magnitude of these responses in the context of a realistic, global environmental perturbation. Together, inter-annual variability and the oscillatory response in MIMICS show less than two percent variation in litter and microbial biomass pools, significantly less than in other microbial models (Wang et al., 2014; sensu Wieder et al., 2014c). Future application of non-linear mod- els, however, should be aware of these characteristics, especially in climate change simulations. The temperature sensitivity and oscillations in litter and microbial biomass pools, however, are dwarfed by large, sustained changes in SOM pools throughout the 21 st century driven by increasing NPP (Figs. 5, 6); therefore, testing the accuracy of projections and their underlying mechanisms in MIMICS is more important than concern over potential oscillations in litter and microbial biomass pools.

\section{Conclusions}

Our study shows that MIMICS improves the representation of soil $\mathrm{C}$ dynamics compared to conventional biogeochemistry models. Moreover, MIMICS offers a platform to develop new understanding of the relationships between microbial communities and SOM dynamics by addressing ecological questions surrounding microbial community composition and soil biogeochemical function. By grouping microbial diversity into simplified functional groups, we demonstrate how community differences may have strong influence over soil $\mathrm{C}$ projections, and show that understanding how functional traits and groups organize across environmental gradients and reorganize following perturbations is needed to parameterize and accurately simulate soil biogeochemical function in ESMs. 


\section{Appendix A: Model description}

\section{A1 Model structure, assumptions, and equations}

The temperature sensitivity of microbial kinetics ( $V_{\max }$ and $K_{\mathrm{m}}$, described in Table B1) are derived from observational data (German et al., 2012; sensu Wieder et al., 2013, 2014c), with modifications based on assumptions regarding microbial functional types (Beardmore et al., 2011; Dethlefsen and Schmidt, 2007; Molenaar et al., 2009), litter chemical quality, and soil texture effects ( $V_{\text {mod }}$ and $K_{\text {mod }}$; Table B1). Building on our previous work (Wieder et al., 2014), the LIDET decomposition study presented here was designed to facilitate parameter estimation (Table B1); however, we note many of these parameter values the are poorly constrained by direct observations. Instead, many parameter values broadly rely on our theoretical understanding of how physiological tradeoffs produce life-history strategies that are optimized for different resource environments (Beardmore et al., 2011; Resat et al., 2012; Russell and Cook, 1995).

For example, fast-growing r-strategists (copiotrophs) are typically characterized by a lower MGE, but higher growth and turnover rates, relative to slower-growing K-strategists (oligotrophs) (Fierer et al., 2007, 2012a; Klappenbach et al., 2000; Pianka, 1970; Ramirez et al., 2012). Given that physiological traits in MIMICS are also sensitive to environmental factors, including temperature and resource chemistry (Frey et al., 2013; Keiblinger et al., 2010; Manzoni et al., 2012; Rousk and Bååth, 2007; Sinsabaugh et al., 2013; Steinweg et al., 2008; Thiet et al., 2006), the physical and chemical resource environment determines the relative abundance of these microbial functional types. We contend that the copiotrophic/oligotrophic framework represented in MIMICS applies to archea, bacteria, and fungi. For example, fungi have a diversity of physiological characteristic that range from extremely copiotrophic (Saccharomyces sp., yeasts) to extremely oligotrophic growth strategies (see Parkinson et al., 1989). We acknowledge that quantifying the relative abundance and physiological characteristics of these growth strategies is an answered challenge for soil scientists; however, the model assumes that the physiological characteristics, as well as ecological function of these organisms, has a greater bearing on soil $\mathrm{C}$ processes than their location on the phylogenetic tree.

Specifically, we assume that the production of microbial biomass will be more rapid and more efficient using substrates from metabolic litter and available SOM pools, and that for a given substrate oligotrophic microbial communities will have a higher MGE than copiotrophs (Kaiser et al., 2014; Wieder et al., 2014c). Turnover of microbial residues (Eqs. A4 and A8) provides inputs to SOM pools that are considered microbial available, chemically recalcitrant, or physically protected, with the latter determined by soil clay content in different soil environments. We assume that size and chemistry of copiotrophic microbial residues may favor physicochemical stabilization in finely textured soils (Grandy and Neff, 2008; Spence et al., 2011) (Table B1).

In MIMICS the size of microbial biomass pools are proportional to the quantity of litter inputs (also see Wang et al., 2014). Although this pattern agrees with observations (Bradford et al., 2013; Fierer et al., 2009), our original parameterization of MIMICS (Wieder et al., 2014) produced biased results when compared to a wider suite of LIDET sites (W. R. Wieder, unpublished data). Specifically, rates of mass loss were more rapid than LIDET observations at higher productivity sites (deciduous forests, conifer forests, and humid grasslands), and too slow in lower productivity sites (tundra, boreal forests, and arid grasslands). To alleviate this bias we normalized microbial turnover rates $(\tau)$ in MIMICS with an empirical relationship based on site-level productivity (or grid cell NPP in global simulations) (Table B1). Observations from soil food-web studies (e.g., Thakur and Eisenhauer, 2015) provide mechanistic support for this modification, where sites with higher microbial biomass, that is to say more productive sites, may support greater top-down control over total microbial biomass.

We also assume that finely textured soils will restrict enzyme access to available $\mathrm{C}$ substrates, here represented by increasing the half saturation constant $\left(K_{\mathrm{m}}\right)$ of available SOM with increasing clay content (Zimmerman and Ahn, 2011). We stress these empirical relationships for partitioning for microbial residues and modifications to microbial kinetics based on clay content that are used here are based on this theoretical understanding, and the numerical constraints of building plausible SOM and microbial biomass pools with co-existence of both microbial functional types across wide biogeographic and edaphic gradients. These simple equations, however, are not constrained by observational estimates, and ignore potentially important influences in soil mineralogy on SOM stabilization.

The model structure employed here assumes that the breakdown and assimilation of chemically recalcitrant SOM is a two-step process involving depolymerization (Eq. A10) and assimilation (Eqs. A3 and A7). This approach has been used by other microbial explicit models (Allison et al., 2010; Wang et al., 2013), and theoretically applies to each pool and flux represented in MIMICS. Here, we make simplifying assumption to omit such dynamics from microbial decomposition of litter pools, focusing on microbial interactions and the breakdown of chemically recalcitrant SOM, as a means to represent the priming of "recalcitrant" SOM with fresh organic (litter) inputs (Kuzyakov, 2010). Parameter values chosen here reflect the greater enzymatic capacity for depolymerization in oligotrophic communities (higher $V_{\max }$ and lower $K_{\mathrm{m}}$ ), but copiotropic communities possess a greater enzymatic capacity for assimilation of $\mathrm{SOM}_{\mathrm{a}}$. Specifically, we assume the $V_{\max }$ of chemically recalcitrant $\mathrm{SOM}\left(\mathrm{SOM}_{\mathrm{c}}\right)$ is approximately similar to structural litter $\left(\mathrm{LIT}_{\mathrm{S}}\right)$ (Table B1); however, mineral soils enzymes have a harder time accessing these substrates. Thus, the parameter KO (Eq. A10) increases 
the half saturation constant $\left(K_{\mathrm{m}}\right)$ for oxidation of $\mathrm{SOM}_{\mathrm{c}}$. Theoretically, KO could also function of soil texture or mineralogy, but for now we isolate mineralogical controls to the uptake of $\mathrm{SOM}_{\mathrm{a}}$ (Eqs. A3 and A7) through the $P_{\text {scalar }}$ parameter.

The size of the microbial biomass pool has no influence on the transfer of physically protected SOM to available SOM pools (Eq. A9). This flux is intended to represent the physical desorption of SOM from mineral surfaces and/or the breakdown of aggregates, with flux rates inversely related to soil clay content. There are no soil respiration losses associated with movement of chemically recalcitrant or physically protected SOM into the available SOM pool. The fluxes $\left(\mathrm{mg} \mathrm{C} \mathrm{cm}{ }^{-3} \mathrm{~h}^{-1}\right)$ from donor to receiver pools and numbered on Fig. 1 are calculated as

$$
\begin{array}{r}
\mathrm{LIT}_{\mathrm{m} \_} \mathrm{MIC}_{\mathrm{r}}=\mathrm{MIC}_{\mathrm{r}} \times V_{\max [\mathrm{r} 1]} \times \mathrm{LIT}_{\mathrm{m}} /\left(K_{\mathrm{m}[\mathrm{r} 1]}+\mathrm{LIT}_{\mathrm{m}}\right), \\
\mathrm{LIT}_{s \_} \mathrm{MIC}_{\mathrm{r}}=\mathrm{MIC}_{\mathrm{r}} \times V_{\max [\mathrm{r} 2]} \times \mathrm{LIT}_{\mathrm{s}} /\left(K_{\mathrm{m}[\mathrm{r} 2]}+\mathrm{LIT}_{\mathrm{s}}\right),
\end{array}
$$

$\mathrm{SOM}_{\mathrm{a} \_} \mathrm{MIC}_{\mathrm{r}}=\mathrm{MIC}_{\mathrm{r}} \times V_{\max [\mathrm{r} 3]} \times \mathrm{SOM}_{\mathrm{a}} /\left(K_{\mathrm{m}[\mathrm{r} 3]}+\mathrm{SOM}_{\mathrm{a}}\right)$,

$$
\begin{aligned}
\mathrm{MIC}_{\mathrm{r} \_} \mathrm{SOM} & =\mathrm{MIC}_{\mathrm{r}} \times \tau_{[\mathrm{r}]}, \\
\mathrm{LIT}_{\mathrm{m} \_} \mathrm{MIC}_{\mathrm{K}} & =\mathrm{MIC}_{\mathrm{K}} \times V_{\max [\mathrm{K} 1]} \times \mathrm{LIT}_{\mathrm{m}} /\left(K_{\mathrm{m}[\mathrm{K} 1]}+\mathrm{LIT}_{\mathrm{m}}\right),
\end{aligned}
$$

$$
\mathrm{LIT}_{\mathrm{s} \_} \mathrm{MIC}_{\mathrm{K}}=\mathrm{MIC}_{\mathrm{K}} \times V_{\max [\mathrm{K} 2]} \times \mathrm{LIT}_{\mathrm{s}} /\left(K_{\mathrm{m}[\mathrm{K} 2]}+\mathrm{LIT}_{\mathrm{s}}\right),
$$

$\mathrm{SOM}_{\mathrm{a} \_} \mathrm{MIC}_{\mathrm{K}}=\mathrm{MIC}_{\mathrm{K}} \times V_{\max [\mathrm{K} 3]} \times \mathrm{SOM}_{\mathrm{a}} /\left(K_{\mathrm{m}[\mathrm{K} 3]}+\mathrm{SOM}_{\mathrm{a}}\right)$,

$$
\begin{aligned}
\mathrm{MIC}_{\mathrm{K} \_} \mathrm{SOM} & =\mathrm{MIC}_{\mathrm{K}} \times \tau_{[\mathrm{K}]}, \\
\mathrm{SOM}_{\mathrm{p} \_} \mathrm{SOM}_{\mathrm{a}} & =\mathrm{SOM}_{\mathrm{p}} \times D, \\
\mathrm{SOM}_{\mathrm{c} \_} \mathrm{SOM}_{\mathrm{a}} & =\left(\mathrm{MIC}_{\mathrm{r}} \times V_{\max [\mathrm{r} 2]} \times \mathrm{SOM}_{\mathrm{c}} /\left(\mathrm{KO}_{[\mathrm{r}]} \times K_{\mathrm{m}[\mathrm{r} 2]}\right.\right. \\
& \left.\left.+\mathrm{SOM}_{\mathrm{c}}\right)\right)+\left(\mathrm{MIC}_{\mathrm{K}} \times V_{\max [\mathrm{K} 2]}\right. \\
& \left.\times \mathrm{SOM}_{\mathrm{c}} /\left(\mathrm{KO}_{[\mathrm{K}]} \times K_{\mathrm{m}[\mathrm{K} 2]}+\mathrm{SOM}_{\mathrm{c}}\right) .\right)
\end{aligned}
$$

Thus, changes in $\mathrm{C}$ pools $\left(\mathrm{mg} \mathrm{Ccm}^{-3}\right)$ can be described using the following equations

$$
\begin{aligned}
& \frac{\mathrm{dLIT}_{\mathrm{m}}}{\mathrm{d} t}=I\left[\mathrm{LIT}_{\mathrm{m}}\right] \times\left(1-f_{\mathrm{i}}, \mathrm{met}\right)-A 1-A 5, \\
& \frac{\mathrm{dLIT}_{\mathrm{s}}}{\mathrm{d} t}=I\left[\mathrm{LIT}_{\mathrm{s}}\right] \times\left(1-f_{\mathrm{i}}, \text { struc }\right)-A 2-A 6, \\
& \frac{\mathrm{dMIC}_{\mathrm{r}}}{\mathrm{d} t}=(\operatorname{MGE}[1] \times A 1)+(\operatorname{MGE}[2] \times A 2) \\
& +(\mathrm{MGE}[1] \times A 3)-A 4, \\
& \frac{\mathrm{dMICK}}{\mathrm{d} t}=(\mathrm{MGE}[3] \times A 5) \\
& +(\operatorname{MGE}[4] \times A 6)+(\operatorname{MGE}[3] \times A 7)-A 8, \\
& \frac{\mathrm{dSOM}_{\mathrm{p}}}{\mathrm{d} t}=I\left[\mathrm{LIT}_{\mathrm{m}}\right] \times f_{\mathrm{i}}, \text { met } \\
& +\left(f_{\mathrm{p}}[r] \times A 4\right)+\left(f_{\mathrm{p}}[K] \times A 8\right)-A 9, \\
& \frac{\mathrm{dSOM}_{\mathrm{c}}}{\mathrm{d} t}=I\left[\mathrm{LIT}_{\mathrm{s}}\right] \times f_{\mathrm{i}}, \operatorname{struc}+\left(f_{\mathrm{c}}[r] \times A 4\right) \\
& +\left(f_{\mathrm{c}}[K] \times A 8\right)-A 10 \\
& \frac{\mathrm{dSOM}_{\mathrm{a}}}{\mathrm{d} t}=\left(f_{\mathrm{a}}[r] \times A 4\right)+\left(f_{\mathrm{a}}[K] \times A 8\right)+A 9 \\
& +A 10-A 3-A 7 \text {. }
\end{aligned}
$$

\section{A2 Cross-site simulations}

To simulate steady-state SOC pools with MIMICS (Table $\mathrm{C} 1$ ), we modified parameters relating to microbial growth efficiency (MGE) and turnover $(\tau)$. Specifically, we decreased the MGE of the copiotrophic community (to 0.5 and 0.2 for metabolic and structural substrates, respectively), and increased the sensitivity of $\mathrm{MIC}_{\mathrm{r}}$ turnover to litter quality $\left(5.2 \times 10^{-4} \times e^{0.6(f \mathrm{met})}\right)$. We also increased microbial turnover threefold over values listed in Table B1.

To match observed changes in the microbial and biogeochemical response to $\mathrm{N}$ enrichment we further modified potential changes to microbial physiology following $\mathrm{N}$ enrichment. These included modifications to MGE, microbial kinetics, and microbial turnover. In the first scenario we increased MGE of the copiotrophic community approximately $10 \%$ (to 0.56 and 0.22 for metabolic and structural substrates, respectively). Effects on steady-state $\mathrm{C}$ pools simulated by MIMICS are described in the main text (Sect. 3.1.2 and Fig. 3). We also explored the likelihood of matching observed soil $\mathrm{C}$ response to $\mathrm{N}$ enrichment by modifying microbial kinetics and turnover ( $V_{\max }$ and $\tau$, respectively). In both of these simulations MGE values were the same as in the LIDET experiment $(0.55$ and 0.25 , for metabolic and structural substrates entering $\mathrm{MIC}_{\mathrm{r}}$ ). In the second scenario, to represent $\mathrm{N}$ inhibition of oxidative enzyme activity (Fog, 1988; Knorr et al., 2005) we decreased the $V_{\max }$ parameter associated with oligotrophic community turnover of structural litter pools and chemically recalcitrant SOM in MIMICS by $15 \%$ (Supplementary Fig. 1a, filled triangles). In the third scenario, to explore how change in microbial turnover may alter steady-state $\mathrm{C}$ pools simulated by MIMICS we 
show results following modifications to $\tau$. Data in Supplementary Fig. 1b (filled triangles) show results following a $6 \%$ increase in the turnover of $\mathrm{MIC}_{\mathrm{K}}$ in response in $\mathrm{N}$ enrichment.

\section{A3 Global simulations}

In moving from cross-site to global simulations we used different estimates of plant productivity, taken from CLM4.5. We also simulated soils $0-100 \mathrm{~cm}$ (rather than $0-30 \mathrm{~cm}$ ). Given these changes, we adjusted parameter values $\tau, f_{\text {met }}$, $f_{\mathrm{c}}$, and $P_{\text {scalar }}$. Parameter changes we made in global simulations served several functions including to maintain both mi- crobial functional groups in most gridcells (Supplementary Fig. 2b), simulate appropriate ratios of MIC : SOC (Supplementary Fig. 2f), and simulate reasonable steady-state SOM distributions (Fig. 4). Specifically, we increased the sensitivity of $\mathrm{MIC}_{\mathrm{r}}$ turnover to litter quality using the formula $\left(5.2 \times 10^{-4} \times e^{0.4(f \mathrm{met})}\right)$. We used the same equation to partition litter inputs into metabolic and structural pools, but reduced total allocation to metabolic pools $15 \%$. We increased the fraction of microbial turnover allocated to the chemically protected pool $\left(f_{\mathrm{c}}\right) 4$ times over the amount listed in Table B1. Finally, we modified the physical protection scalar using the following equation $P_{\text {scalar }}=\left(0.8 \times e^{-3 \sqrt{f_{\text {clay }}}}\right)^{-1}$. 


\section{Appendix B}

Table B1. MIMICS parameters, values, and units used for LIDET simulations.

\begin{tabular}{|c|c|c|c|}
\hline Parameter & Description & Value & Units \\
\hline$f_{\text {met }}$ & Partitioning of litter inputs to $\mathrm{LIT}_{\mathrm{m}}$ & $0.85-0.013($ lignin/N) & - \\
\hline$f_{\mathrm{i}}$ & Fraction of litter inputs transferred to SOM & $0.05,0.05^{\mathrm{a}}$ & - \\
\hline$V_{\text {slope }}$ & Regression coefficient (Eq. 1) & $0.063^{\mathrm{b}}$ & $\ln \left(\mathrm{mg} C_{\mathrm{S}}(\mathrm{mg} \mathrm{MIC})^{-1} \mathrm{~h}^{-1}\right)^{\circ} \mathrm{C}^{-1}$ \\
\hline$V_{\text {int }}$ & Regression intercept (Eq. 1) & $5.47^{\mathrm{b}}$ & $\ln \left(\mathrm{mg} C_{\mathrm{S}}(\mathrm{mg} \mathrm{MIC})^{-1} \mathrm{~h}^{-1}\right)$ \\
\hline$a_{\mathrm{V}}$ & Tuning coefficient (Eq. 1) & $8 \times 10^{-6 b}$ & - \\
\hline$V_{\text {mod-r }}$ & Modifies $V_{\max }$ for fluxes into $\mathrm{MIC}_{\mathrm{r}}$ & $10,2,10^{\mathrm{c}}$ & - \\
\hline$V_{\text {mod-K }}$ & Modifies $V_{\max }$ for fluxes into $\mathrm{MIC}_{\mathrm{K}}$ & $3,3,2^{\mathrm{d}}$ & - \\
\hline$K_{\text {slope }}$ & Regression coefficient (Eq. 2) & $0.017,0.027,0.017^{\mathrm{c}, \mathrm{d}}$ & $\ln \left(\mathrm{mg} \mathrm{C} \mathrm{cm}{ }^{-3}\right){ }^{\circ} \mathrm{C}^{-1}$ \\
\hline$K_{\text {int }}$ & Regression intercept (Eq. 2) & $3.19^{\mathrm{b}}$ & $\ln \left(\mathrm{mg} \mathrm{C} \mathrm{cm}^{-3}\right)$ \\
\hline$a_{\mathrm{K}}$ & Tuning coefficient (Eq. 2) & $10^{\mathrm{b}}$ & - \\
\hline$K_{\text {mod-r }}$ & Modifies $K_{\mathrm{m}}$ for fluxes into $\mathrm{MIC}_{\mathrm{r}}$ & $0.125,0.5,0.25 \times P_{\text {scalar }}^{\mathrm{c}}$ & - \\
\hline$K_{\text {mod-K }}$ & Modifies $K_{\mathrm{m}}$ for fluxes into $\mathrm{MIC}_{\mathrm{K}}$ & $0.5,0.25,0.167 \times P_{\text {scalar }, \mathrm{d}}$ & - \\
\hline$P_{\text {scalar }}$ & Physical protection scalar used in $K_{\text {mod }}$ & $\left(2.0 \times e^{-2 \sqrt{f_{\text {clay }}}}\right)^{-1}$ & - \\
\hline MGE & Microbial growth efficiency & $0.55,0.25,0.75,0.35^{\mathrm{e}}$ & $\mathrm{mg} \mathrm{mg}^{-1}$ \\
\hline$\tau$ & Microbial biomass turnover rate & $\begin{array}{l}5.2 \times 10^{-4} \times e^{0.3\left(f_{\mathrm{met}}\right)} \times \tau_{\mathrm{mod}} \\
2.4 \times 10^{-4} \times e^{0.1\left(f_{\mathrm{met}}\right)} \times \tau_{\mathrm{mod}}^{\mathrm{f}}\end{array}$ & $\mathrm{h}^{-1}$ \\
\hline$\tau_{\mathrm{mod}}$ & Modifies microbial turnover rate & $0.8<\sqrt{\mathrm{NPP} / 100}<1.2$ & - \\
\hline$f_{\mathrm{p}}$ & Fraction of $\tau$ partitioned to $\mathrm{SOM}_{\mathrm{p}}$ & $0.3 \times e^{1.3\left(f_{\text {clay }}\right)}, 0.2 \times e^{0.8\left(f_{\text {clay }}\right), \mathrm{f}}$ & - \\
\hline$f_{\mathrm{c}}$ & Fraction of $\tau$ partitioned to $\mathrm{SOM}_{\mathrm{c}}$ & $0.1 \times e^{-3\left(f_{\mathrm{met}}\right)}, 0.3 \times e^{-3\left(f_{\mathrm{met}}\right), \mathrm{f}}$ & - \\
\hline$f_{\mathrm{a}}$ & Fraction of $\tau$ partitioned to $\mathrm{SOM}_{\mathrm{a}}$ & $1-\left(f_{\mathrm{p}}+f_{\mathrm{c}}\right)^{\mathrm{f}}$ & - \\
\hline$D$ & Desorbsion rate from $\mathrm{SOM}_{\mathrm{p}}$ to $\mathrm{SOM}_{\mathrm{a}}$ & $1.5 \times 10^{-5} \times e^{-1.5\left(f_{\text {clay }}\right)}$ & $\mathrm{h}^{-1}$ \\
\hline KO & Further modifies $K_{\mathrm{m}}$ for oxidation of $\mathrm{SOM}_{\mathrm{c}}$ & $4,4^{\mathrm{f}}$ & - \\
\hline
\end{tabular}

${ }^{a}$ For metabolic litter inputs entering $\mathrm{SOM}_{\mathrm{p}}$ and structural litter inputs entering $\mathrm{SOM}_{\mathrm{c}}$, respectively.

${ }^{b}$ From observations in German et al. (2012), as used in Wieder et al. (2013, 2014c).

${ }^{\mathrm{c}}$ For $\mathrm{LIT}_{\mathrm{m}}, \mathrm{LIT}_{\mathrm{s}}$, and $\mathrm{SOM}_{\mathrm{a}}$, fluxes entering $\mathrm{MIC}_{\mathrm{r}}$, respectively.

${ }^{\mathrm{d}}$ For $\mathrm{LIT}_{\mathrm{m}}, \mathrm{LIT}_{\mathrm{s}}$, and $\mathrm{SOM}_{\mathrm{a}}$, fluxes entering $\mathrm{MIC}_{\mathrm{K}}$, respectively.

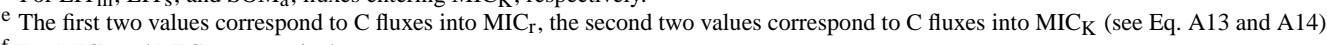

${ }^{\mathrm{f}}$ For $\mathrm{MIC}_{\mathrm{r}}$ and $\mathrm{MIC}_{\mathrm{K}}$, respectively.

g NPP units $=\mathrm{g} \mathrm{C} \mathrm{m}^{-2} \mathrm{y}^{-1}$. 
Appendix C: LTER study sites and bioclimatic information

Table C1. Mean annual temperature and precipitation (MAT and MAP, respectively) (Harmon, 2013); edaphic properties (0-10 cm) (Zak et al., 1994); aboveground net primary productivity (ANPP) (Knapp and Smith, 2001); litter chemistry (Brovkin et al., 2012); and steadystate SOM pools simulated by DAYCENT and MIMICS $(0-30 \mathrm{~cm})$. Data from other sources are marked with asterisks and noted below. Where no soil texture data were available (ARC and BNZ) we used $50 \%$ sand and $5 \%$ clay for DAYCENT and MIMICS simulations. Litter characteristics for KBS follow those for grassland sites.

\begin{tabular}{lcccccccccc}
\hline Site & $\begin{array}{c}\text { MAT } \\
{ }^{\circ} \mathrm{C}\end{array}$ & $\begin{array}{c}\mathrm{MAP} \\
\mathrm{mm}\end{array}$ & $\begin{array}{c}\text { soil C } \\
\mathrm{kg} \mathrm{C} \mathrm{m}^{-2}\end{array}$ & $\begin{array}{c}\text { Sand } \\
\%\end{array}$ & $\begin{array}{c}\text { Clay } \\
\%\end{array}$ & $\begin{array}{c}\text { ANPP } \\
\mathrm{g} \mathrm{C} \mathrm{m}^{-2} \mathrm{y}^{-1}\end{array}$ & $\begin{array}{c}\text { Lignin } \\
\%\end{array}$ & $\begin{array}{c}\text { Litter } \\
\mathrm{C}: \mathrm{N}\end{array}$ & $\begin{array}{c}\text { DAYCENT } \\
\mathrm{kg} \mathrm{C} \mathrm{m}^{-2}\end{array}$ & $\begin{array}{c}\text { MIMICS } \\
\mathrm{kg} \mathrm{C} \mathrm{m}^{-2}\end{array}$ \\
\hline Arctic (ARC) & -7 & 327 & $4.9^{*}$ & - & - & 71 & 16.6 & 36.5 & 4.2 & 6.1 \\
Bonanza Creek (BNZ) & -5 & 403 & $6.5^{*}$ & - & - & 150 & 25.6 & 52.1 & 7.5 & 9.2 \\
Niwot Ridge (NWT) & -3.7 & 1249 & 7.1 & 50 & 6 & 100 & 16.6 & 36.5 & 6.0 & 8.4 \\
Hubbard Brook (HBR) & 5 & 1396 & 8.9 & 71 & 3 & 352 & 21 & 49.0 & 5.4 & 5.8 \\
Cedar Creek Reserve (CDR) & 5.5 & 823 & 2.5 & 87 & 4 & 139 & 16.6 & 36.5 & 1.9 & 4.8 \\
Harvard Forest (HFR) & 7.1 & 1152 & $4.6^{*}$ & $64^{*}$ & $15^{*}$ & 372 & 21 & 49.0 & 6.8 & 6.6 \\
Andrews Forest (AND) & 8.6 & 2309 & 6.5 & 55 & 11 & $400^{*}$ & 24.4 & 68.5 & 9.6 & 6.3 \\
Shortgrass Steppe (SGS) & 8.9 & 440 & 1.6 & 57 & 24 & 58 & 16.6 & 36.5 & 2.7 & 3.5 \\
Kellogg Bio. Station (KBS) & 9.7 & 890 & $4.0^{*}$ & $50^{*}$ & $17^{*}$ & 216 & 21 & 49.0 & 4.0 & 5.5 \\
Coweeta (CWT) & 12.5 & 1906 & 3.9 & 55 & 17 & $730^{*}$ & 21 & 49.0 & 9.8 & 7.2 \\
Konza Prairie (KNZ) & 12.8 & 791 & 4.6 & 11 & 39 & 222 & 16.6 & 36.5 & 5.7 & 6.6 \\
Jornada (JRN) & 14.6 & 298 & 0.65 & 82 & 10 & 115 & 16.6 & 36.5 & 4.3 & 3.2 \\
Sevilleta (SEV) & 16 & 254 & 0.4 & 74 & 12 & 92 & 16.6 & 36.5 & 4.5 & 2.8 \\
Luquillo (LUQ) & 23 & 3363 & $4.1^{*}$ & $51^{*}$ & $32^{*}$ & $525^{*}$ & 17.8 & 52.6 & 3.8 & 6.2 \\
\hline
\end{tabular}

* Data for: ARC (Mineral soil), no depth reported; (Mack et al., 2004) BNZ (O horizon) (Waldrop et al., 2012); HFR (C. Lajtha and S. Frey, unpublished data); AND (Zak et al., 1994); KBS ( 0-20 cm) (Syswerda et al., 2011); CWT (Zak et al., 1994); LUQ (Beinroth, 1982; Cleveland et al., 2011; Frank et al., 2012). 


\section{Code availability}

Codes which generated the MIMICS results presented in Fig. 2 and Table 1 of the manuscript are now publicly available on GitHub (https://github.com/wwieder/MIMICS/ releases/tag/MIMICS_v0.1). Other code is available upon request towwieder@ucar.edu.

\section{The Supplement related to this article is available online at doi:10.5194/gmd-8-1789-2015-supplement.}

Author contributions. W. R. Wieder, A. S. Grandy and C. M. Kallenbach developed the model code. W. R. Wieder, P. G. Taylor, and G. B. Bonan designed the experiments. W. R. Wieder carried performed the simulations and prepared the manuscript with contributions from all co-authors.

Acknowledgements. The National Center for Atmospheric Research is sponsored by the National Science Foundation. National Science Foundation grants EF-1048481, AGS-1020767 and DEB-1027341 supported W. R. Wieder. A. S. Grandy received financial support from the USDA (2009-65107-05961) and US DOE (DE-FCO2-07ER64494 and DE-ACO5-76RL01830). C. M. Kallenbach was supported by NSF (BIO-1311501) and USDA-NIFA (2014-67011-21569). P. G. Taylor was supported by NSF (DEB-0515744 and DEB-0852916).

Edited by: J. Williams

\section{References}

Adair, E. C., Parton, W. J., Del Grosso, S. J., Silver, W. L., Harmon, M. E., Hall, S. A., Burkes, I. C., and Hart, S. C.: Simple three-pool model accurately describes patterns of long-term litter decomposition in diverse climates, Global Change Biol., 14, 2636-2660, 2008.

Allison, S. D.: A trait-based approach for modelling microbial litter decomposition, Ecol. Lett., 15, 1058-1070, 2012.

Allison, S. D., Wallenstein, M. D., and Bradford, M. A.: Soil-carbon response to warming dependent on microbial physiology, Nature Geosci., 3, 336-340, 2010.

Arora, V. K., Boer, G. J., Friedlingstein, P., Eby, M., Jones, C. D., Christian, J. R., Bonan, G., Bopp, L., Brovkin, V., Cadule, P., Hajima, T., Ilyina, T., Lindsay, K., Tjiputra, J. F., and Wu, T.: Carbon-Concentration and Carbon-Climate Feedbacks in CMIP5 Earth System Models, J. Climate, 26, 5289-5314, 2013.

Barton, A. D., Pershing, A. J., Litchman, E., Record, N. R., Edwards, K. F., Finkel, Z. V., Kiørboe, T., and Ward, B. A.: The biogeography of marine plankton traits, Ecol. Lett., 16, 522-534, 2013.

Beardmore, R. E., Gudelj, I., Lipson, D. A., and Hurst, L. D.: Metabolic trade-offs and the maintenance of the fittest and the flattest, Nature, 472, 342-346, 2011.
Beinroth, F. H.: Some highly weathered soils of Puerto Rico, 1. Morphology, formation and classification, Geoderma, 27, 1-73, 1982.

Berg, G. and Smalla, K.: Plant species and soil type cooperatively shape the structure and function of microbial communities in the rhizosphere, FEMS Microbiol. Ecol., 68, 1-13, 2009.

Bonan, G. B., Hartman, M. D., Parton, W. J., and Wieder, W. R.: Evaluating litter decomposition in earth system models with long-term litterbag experiments: an example using the Community Land Model version 4 (CLM4), Global Change Biol., 19, 957-974, 2013.

Bowden, R. D., Deem, L., Plante, A. F., Peltre, C., Nadelhoffer, K., and Lajtha, K.: Litter Input Controls on Soil Carbon in a Temperate Deciduous Forest, Soil Sci. Soc. Am. J., 78, S66-S75, 2014.

Bradford, M. A.: Thermal adaptation of decomposer communities in warming soils, Front. Microbiol., 4, 333, 2013.

Bradford, M., Keiser, A., Davies, C., Mersmann, C., and Strickland, M.: Empirical evidence that soil carbon formation from plant inputs is positively related to microbial growth, Biogeochemistry, 113, 271-281, 2013.

Brovkin, V., van Bodegom, P. M., Kleinen, T., Wirth, C., Cornwell, W. K., Cornelissen, J. H. C., and Kattge, J.: Plant-driven variation in decomposition rates improves projections of global litter stock distribution, Biogeosciences, 9, 565-576, doi:10.5194/bg-9-5652012, 2012.

Canty, A. and Ripley, B.: boot: Bootstrap R (S-Plus) Functions, R package version 1.3-9, 2013.

Chen, R., Senbayram, M., Blagodatsky, S., Myachina, O., Dittert, K., Lin, X., Blagodatskaya, E., and Kuzyakov, Y.: Soil C and N availability determine the priming effect: microbial $\mathrm{N}$ mining and stoichiometric decomposition theories, Global Change Biol., 20, 2356-2367, 2014.

Cleveland, C. C., Townsend, A. R., Taylor, P., Alvarez-Clare, S., Bustamante, M. M. C., Chuyong, G., Dobrowski, S. Z., Grierson, P., Harms, K. E., Houlton, B. Z., Marklein, A., Parton, W. Porder, S., Reed, S. C., Sierra, C. A., Silver, W. L., Tanner, E. V. J., and Wieder, W. R.: Relationships among net primary productivity, nutrients and climate in tropical rain forest: a pan-tropical analysis, Ecol. Lett., 14, 939-947, 2011.

Davidson, E. A., Savage, K. E., and Finzi, A. C.: A big-microsite framework for soil carbon modeling, Global Change Biol., 20, 3610-3620, 2014.

Dethlefsen, L. and Schmidt, T. M.: Performance of the Translational Apparatus Varies with the Ecological Strategies of Bacteria, J. Bacteriol., 189, 3237-3245, 2007.

Dungait, J. A. J., Hopkins, D. W., Gregory, A. S., and Whitmore, A. P.: Soil organic matter turnover is governed by accessibility not recalcitrance, Global Change Biol., 18, 1781-1796, 2012.

Dutkiewicz, S., Scott, J. R., and Follows, M. J.: Winners and losers: Ecological and biogeochemical changes in a warming ocean, Global Biogeochem. Cycles, 27, 463-477, 2013.

FAO, IIASA, ISRIC, ISSCAS, and JRC: Harmonized World Soil Database (version 1.2), edited by: FAO, Rome, Italy and IIASA, Laxenburg, Austria, 2012.

Fierer, N., Bradford, M. A., and Jackson, R. B.: Toward an ecological classification of soil bacteria, Ecology, 88, 1354-1364, 2007.

Fierer, N., Strickland, M. S., Liptzin, D., Bradford, M. A., and Cleveland, C. C.: Global patterns in belowground communities, Ecol. Lett., 12, 1238-1249, 2009. 
Fierer, N., Lauber, C. L., Ramirez, K. S., Zaneveld, J., Bradford, M. A., and Knight, R.: Comparative metagenomic, phylogenetic and physiological analyses of soil microbial communities across nitrogen gradients, ISME J., 6, 1007-1017, 2012a.

Fierer, N., Leff, J. W., Adams, B. J., Nielsen, U. N., Bates, S. T., Lauber, C. L., Owens, S., Gilbert, J. A., Wall, D. H., and Caporaso, J. G.: Cross-biome metagenomic analyses of soil microbial communities and their functional attributes, Proc. Natl. Acad. Sci., 109, 21390-21395, 2012b.

Fog, K.: The effect of added nitrogen on the rate of decomposition of organic matter, Biol. Rev. Camb. Philos. Soc., 63, 433-462, 1988.

Follows, M. J., Dutkiewicz, S., Grant, S., and Chisholm, S. W.: Emergent Biogeography of Microbial Communities in a Model Ocean, Science, 315, 1843-1846, 2007.

Fontaine, S. and Barot, S.: Size and functional diversity of microbe populations control plant persistence and long-term soil carbon accumulation, Ecol. Lett., 8, 1075-1087, 2005.

Frank, D., Pontes, A., and McFarlane, K.: Controls on Soil Organic Carbon Stocks and Turnover Among North American Ecosystems, Ecosystems, 15, 604-615, 2012.

Frey, S. D., Knorr, M., Parrent, J. L., and Simpson, R. T.: Chronic nitrogen enrichment affects the structure and function of the soil microbial community in temperate hardwood and pine forests, For. Ecol. Manag., 196, 159-171, 2004.

Frey, S. D., Lee, J., Melillo, J. M., and Six, J.: The temperature response of soil microbial efficiency and its feedback to climate, Nature Clim. Change, 3, 395-398, 2013.

Gallo, M., Amonette, R., Lauber, C., Sinsabaugh, R. L., and Zak, D. R.: Microbial community structure and oxidative enzyme activity in nitrogen-amended north temperate forest soils, Microb. Ecol., 48, 218-229, 2004.

German, D. P., Marcelo, K. R. B., Stone, M. M., and Allison, S. D.: The Michaelis-Menten kinetics of soil extracellular enzymes in response to temperature: a cross-latitudinal study, Global Change Biol., 18, 1468-1479, 2012.

Grandy, A. S. and Neff, J. C.: Molecular C dynamics downstream: The biochemical decomposition sequence and its impact on soil organic matter structure and function, Sci. Tot. Environ., 404, 297-307, 2008.

Hagerty, S. B., van Groenigen, K. J., Allison, S. D., Hungate, B. A., Schwartz, E., Koch, G. W., Kolka, R. K., and Dijkstra, P.: Accelerated microbial turnover but constant growth efficiency with warming in soil, Nature Clim. Change, 4, 903-906, 2014.

Hararuk, O., Smith, M. J., and Luo, Y.: Microbial models with datadriven parameters predict stronger soil carbon responses to climate change, Global Change Biol., 21, 2439-2453, 2015.

Harmon, M. E.: LTER Intersite Fine Litter Decomposition Experiment (LIDET), 1990 to 2002. Long-Term Ecological Research, edited by: Bank, F. S. D., Corvallis, OR., 2013.

Harmon, M. E., Silver, W. L., Fasth, B., Chen, H. U. A., Burke, I. C., Parton, W. J., Hart, S. C., Currie, W. S., and LIDET: Longterm patterns of mass loss during the decomposition of leaf and fine root litter: an intersite comparison, Global Change Biol., 15, 1320-1338, 2009.

Hobbie, S. E.: Nitrogen effects on decomposition: a five-year experiment in eight temperate sites, Ecology, 89, 2633-2644, 2008.

Hungate, B. A., Van Groenigen, K.-J., Six, J., Jastrow, J. D., Luo, Y., De Graaff, M.-A., Van Kessel, C., and Osenberg, C. W.: Assess- ing the effect of elevated carbon dioxide on soil carbon: a comparison of four meta-analyses, Global Change Biol., 15, 20202034, 2009.

Janssens, I. A., Dieleman, W., Luyssaert, S., Subke, J. A., Reichstein, M., Ceulemans, R., Ciais, P., Dolman, A. J., Grace, J., Matteucci, G., Papale, D., Piao, S. L., Schulze, E. D., Tang, J., and Law, B. E.: Reduction of forest soil respiration in response to nitrogen deposition, Nature Geosci., 3, 315-322, 2010.

Kaiser, C., Franklin, O., Dieckmann, U., and Richter, A.: Microbial community dynamics alleviate stoichiometric constraints during litter decay, Ecol. Lett., 17, 680-690, 2014.

Keiblinger, K. M., Hall, E. K., Wanek, W., Szukics, U., Hämmerle, I., Ellersdorfer, G., Böck, S., Strauss, J., Sterflinger, K., Richter, A., and Zechmeister-Boltenstern, S.: The effect of resource quantity and resource stoichiometry on microbial carbonuse-efficiency, FEMS Microbiol. Ecol., 73, 430-440, 2010.

Klappenbach, J. A., Dunbar, J. M., and Schmidt, T. M.: rRNA Operon Copy Number Reflects Ecological Strategies of Bacteria, Appl. Environ. Microbiol., 66, 1328-1333, 2000.

Knapp, A. K. and Smith, M. D.: Variation among biomes in temporal dynamics of aboveground primary production, Science, 291, 481-484, 2001.

Knorr, M., Frey, S. D., and Curtis, P. S.: Nitrogen additions and litter decomposition: A meta-analysis, Ecology, 86, 3252-3257, 2005.

Koch, A. L.: Oligotrophs versus copiotrophs, BioEssays, 23, 657661, 2001.

Krause, S., Le Roux, X., Niklaus, P. A., Bodegom, P. V., Lennon, J. T., Bertilsson, S., Grossart, H.-P., Philippot, L., and Bodelier, P.: Trait-based approaches for understanding microbial biodiversity and ecosystem functioning, Front. Microbiol., 5, 251, 2014.

Kuzyakov, Y.: Priming effects: Interactions between living and dead organic matter, Soil Biol. Biochemistry, 42, 1363-1371, 2010.

Lajtha, K., Bowden, R. D., and Nadelhoffer, K.: Litter and Root Manipulations Provide Insights into Soil Organic Matter Dynamics and Stability, Soil Sci. Soc. Am. J., 78, S261-S269, 2014.

Leff, J. W., Wieder, W. R., Taylor, P. G., Townsend, A. R., Nemergut, D. R., Grandy, A. S., and Cleveland, C. C.: Experimental litterfall manipulation drives large and rapid changes in soil carbon cycling in a wet tropical forest, Global Change Biol., 18, 2969-2979, 2012.

Li, J., Wang, G., Allison, S. D., Mayes, M. A., and Luo, Y.: Soil carbon sensitivity to temperature and carbon use efficiency compared across microbial-ecosystem models of varying complexity, Biogeochemistry, 119, 67-84, 2014.

Litchman, E. and Klausmeier, C. A.: Trait-Based Community Ecology of Phytoplankton, Annu. Rev. Ecol., Evolut., Syst., 39, 615639, 2008.

Litchman, E., Ohman, M. D., and Kiørboe, T.: Trait-based approaches to zooplankton communities, J. Plankton Res., 35, 473484, 2013.

Liu, L. L. and Greaver, T. L.: A global perspective on belowground carbon dynamics under nitrogen enrichment, Ecol. Lett., 13, 819-828, 2010.

Lu, M., Zhou, X., Luo, Y., Yang, Y., Fang, C., Chen, J., and Li, B.: Minor stimulation of soil carbon storage by nitrogen addition: A meta-analysis, Agriculture, Ecosyst. Environ., 140, 234-244, 2011.

Mack, M. C., Schuur, E. A. G., Bret-Harte, M. S., Shaver, G. R., and Chapin III, F. S.: Ecosystem carbon storage in arctic tundra re- 
duced by long-term nutrient fertilization, Nature, 431, 440-443, 2004

Manzoni, S., Taylor, P., Richter, A., Porporato, A., and Ågren, G. I.: Environmental and stoichiometric controls on microbial carbonuse efficiency in soils, New Phytologist, 196, 79-91, 2012.

Mendes, L. W., Kuramae, E. E., Navarrete, A. A., van Veen, J. A., and Tsai, S. M.: Taxonomical and functional microbial community selection in soybean rhizosphere, ISME J., 8, 1577-1587, 2014.

Miki, T., Ushio, M., Fukui, S., and Kondoh, M.: Functional diversity of microbial decomposers facilitates plant coexistence in a plant-microbe-soil feedback model, Proc. Natl. Acad. Sci., 107, 14251-14256, 2010.

Miltner, A., Bombach, P., Schmidt-Brücken, B., and Kästner, M.: SOM genesis: microbial biomass as a significant source, Biogeochemistry, 111, 41-55, 2012.

Molenaar, D., van Berlo, R., de Ridder, D., and Teusink, B.: Shifts in growth strategies reflect tradeoffs in cellular economics, Molec. Syst. Biol., 5, 323, 2009.

Parkinson, S. M., Wainwright, M., and Killham, K.: Observations on oligotrophic growth of fungi on silica gel, Mycol. Res., 93, 529-534, 1989.

Parton, W. J., Schimel, D. S., Cole, C. V., and Ojima, D. S.: Analysis of factors controlling soil organic-matter levels in Great-Plains grasslands, Soil Sci. Soc. Am. J., 51, 1173-1179, 1987.

Parton, W. J., Schimel, D. S., Cole, C. V., and Ojima, D. S.: A general model for soil organic matter dynamics: sensitivity to litter chemistry, texture and management, in: Quantitative modeling of soil forming processes, edited by: Bryant, R. B., and Arnold, R. W., Soil Sci. Soc. Am., Minneapolis, Minnesota, USA, 1994.

Parton, W., Silver, W. L., Burke, I. C., Grassens, L., Harmon, M. E., Currie, W. S., King, J. Y., Adair, E. C., Brandt, L. A., Hart, S. C., and Fasth, B.: Global-scale similarities in nitrogen release patterns during long-term decomposition, Science, 315, 361-364, 2007.

Perveen, N., Barot, S., Alvarez, G., Klumpp, K., Martin, R., Rapaport, A., Herfurth, D., Louault, F., and Fontaine, S.: Priming effect and microbial diversity in ecosystem functioning and response to global change: a modeling approach using the SYMPHONY model, Global Change Biol., 20, 1174-1190, 2014.

Pianka, E. R.: On r- and K-Selection, The American Naturalist, 104, 592-597, 1970.

Ramirez, K. S., Craine, J. M., and Fierer, N.: Consistent effects of nitrogen amendments on soil microbial communities and processes across biomes, Global Change Biol., 18, 1918-1927, 2012.

Reich, P. B.: The world-wide "fast-slow" plant economics spectrum: a traits manifesto, J. Ecol., 102, 275-301, 2014.

Reichstein, M., Bahn, M., Mahecha, M. D., Kattge, J., and Baldocchi, D. D.: Linking plant and ecosystem functional biogeography, Proc. Natl. Acad. Sci. USA, 111, 13697-13702, 2014.

Resat, H., Bailey, V., McCue, L., and Konopka, A.: Modeling Microbial Dynamics in Heterogeneous Environments: Growth on Soil Carbon Sources, Microb. Ecol., 63, 883-897, 2012.

Rousk, J. and Bååth, E.: Fungal and bacterial growth in soil with plant materials of different C/N ratios, FEMS Microbiol. Ecol., 62, 258-267, 2007.

R Team R: A Language and Environment for Statistical Computing, R Foundation for Statistical Computing, Vienna, Austria, 2014.
Russell, J. B. and Cook, G. M.: Energetics of bacterial growth: balance of anabolic and catabolic reactions, Microbiol. Rev., 59, 4862, 1995.

Saiya-Cork, K. R., Sinsabaugh, R. L., and Zak, D. R.: The effects of long term nitrogen deposition on extracellular enzyme activity in an Acer saccharum forest soil, Soil Biol. Biochemistry, 34, 1309-1315, 2002.

Sayer, E. J., Heard, M. S., Grant, H. K., Marthews, T. R., and Tanner, E. V. J.: Soil carbon release enhanced by increased tropical forest litterfall, Nature Clim. Change, 1, 304-307, 2011.

Schimel, J. and Schaeffer, S. M.: Microbial control over carbon cycling in soil, Front. Microbiol., 3, 348, 2012.

Schmidt, M. W. I., Torn, M. S., Abiven, S., Dittmar, T., Guggenberger, G., Janssens, I. A., Kleber, M., Kogel-Knabner, I., Lehmann, J., Manning, D. A. C., Nannipieri, P., Rasse, D. P., Weiner, S., and Trumbore, S. E.: Persistence of soil organic matter as an ecosystem property, Nature, 478, 49-56, 2011.

Serna-Chavez, H. M., Fierer, N., and van Bodegom, P. M.: Global drivers and patterns of microbial abundance in soil, Global Ecol. Biogeogr., 22, 1162-1172, 2013.

Sinsabaugh, R. L., Manzoni, S., Moorhead, D. L., and Richter, A.: Carbon use efficiency of microbial communities: stoichiometry, methodology and modelling, Ecol. Lett., 16, 930-939, 2013.

Soetaert, K.: rootSolve: Nonlinear root finding, equilibrium and steady-state analysis of ordinary differential equations, R package version 1.6, 2009.

Sollins, P., Homann, P., and Caldwell, B. A.: Stabilization and destabilization of soil organic matter: Mechanisms and controls, Geoderma, 74, 65-105, 1996.

Sommer, U.: The role of $\mathrm{r}$ - and k-selection in the succession of phytoplankton in Lake Constance, Acta Oecologia, 2, 327-342, 1981.

Spence, A., Simpson, A. J., McNally, D. J., Moran, B. W., McCaul, M. V., Hart, K., Paull, B., and Kelleher B. P.: The degradation characteristics of microbial biomass in soil, Geochim. Cosmoch. Acta, 75, 2571-2781, 2011.

Steinweg, J. M., Plante, A. F., Conant, R. T., Paul, E. A., and Tanaka, D. L.: Patterns of substrate utilization during long-term incubations at different temperatures, Soil Biol. Biochem., 40, 2722-2728, 2008.

Sulman, B. N., Phillips, R. P., Oishi, A. C., Shevliakova, E., and Pacala, S. W.: Microbe-driven turnover offsets mineral-mediated storage of soil carbon under elevated $\mathrm{CO}_{2}$, Nature Clim. Change, 4, 1099-1102, 2014.

Syswerda, S. P., Corbin, A. T., Mokma, D. L., Kravchenko, A. N., and Robertson, G. P.: Agricultural management and soil carbon storage in surface vs. deep layers, Soil Sci. Soc. Am. J., 75, 92 $101,2011$.

Tang, J. and Riley, W. J.: Weaker soil carbon-climate feedbacks resulting from microbial and abiotic interactions, Nature Clim. Change, 5, 56-60, 2014.

Thakur, M. P. and Eisenhauer, N.: Plant community composition determines the strength of top-down control in a soil food web motif, Scientific Reports, 5, 9134, 2015.

Thiet, R. K., Frey, S. D., and Six, J.: Do growth yield efficiencies differ between soil microbial communities differing in fungal:bacterial ratios? Reality check and methodological issues, Soil Biol. Biochem., 38, 837-844, 2006. 
Todd-Brown, K. E. O., Randerson, J. T., Post, W. M., Hoffman, F. M., Tarnocai, C., Schuur, E. A. G., and Allison, S. D.: Causes of variation in soil carbon simulations from CMIP5 Earth system models and comparison with observations, Biogeosciences, 10, 1717-1736, doi:10.5194/bg-10-1717-2013, 2013.

Todd-Brown, K. E. O., Randerson, J. T., Hopkins, F., Arora, V., Hajima, T., Jones, C., Shevliakova, E., Tjiputra, J., Volodin, E., Wu, T., Zhang, Q., and Allison, S. D.: Changes in soil organic carbon storage predicted by Earth system models during the 21st century, Biogeosciences, 11, 2341-2356, doi:10.5194/bg-11-23412014, 2014.

Treseder, K., Balser, T., Bradford, M., Brodie, E., Dubinsky, E., Eviner, V., Hofmockel, K., Lennon, J., Levine, U., MacGregor, B., Pett-Ridge, J., and Waldrop, M.: Integrating microbial ecology into ecosystem models: challenges and priorities, Biogeochemistry, 109, 7-18, 2012.

Vallina, S. M., Follows, M. J., Dutkiewicz, S., Montoya, J. M., Cermeno, P., and Loreau, M.: Global relationship between phytoplankton diversity and productivity in the ocean, Nature Communications, 5, 4299, 2014.

van Bodegom, P. M., Douma, J. C., and Verheijen, L. M.: A fully traits-based approach to modeling global vegetation distribution, Proc. Natl. Acad. Sci. USA, 111, 13733-13738, 2014.

van Groenigen, K. J., Qi, X., Osenberg, C. W., Luo, Y., and Hungate, B. A.: Faster Decomposition Under Increased Atmospheric $\mathrm{CO}_{2}$ Limits Soil Carbon Storage, Science, 344, 508-509, 2014.

Waldrop, M. P., Zak, D. R., Sinsabaugh, R. L., Gallo, M., and Lauber, C.: Nitrogen deposition modifies soil carbon storage through changes in microbial enzymatic activity, Ecological Applications, 14, 1172-1177, 2004.

Waldrop, M. P., Harden, J. W., Turetsky, M. R., Petersen, D. G., McGuire, A. D., Briones, M. J. I., Churchill, A. C., Doctor, D. H., and Pruett, L. E.: Bacterial and enchytraeid abundance accelerate soil carbon turnover along a lowland vegetation gradient in interior Alaska, Soil Biol. Biochem., 50, 188-198, 2012.

Wang, G., Post, W. M., and Mayes, M. A.: Development of microbial-enzyme-mediated decomposition model parameters through steady-state and dynamic analyses, Ecol. Applic., 23, 255-272, 2013.
Wang, Y. P., Chen, B. C., Wieder, W. R., Leite, M., Medlyn, B. E., Rasmussen, M., Smith, M. J., Agusto, F. B., Hoffman, F., and Luo, Y. Q.: Oscillatory behavior of two nonlinear microbial models of soil carbon decomposition, Biogeosciences, 11, 18171831, doi:10.5194/bg-11-1817-2014, 2014.

Wieder, W. R., Bonan, G. B., and Allison, S. D.: Global soil carbon projections are improved by modelling microbial processes, Nature Clim. Change, 3, 909-912, 2013.

Wieder, W. R., Boehnert, J., and Bonan, G. B.: Evaluating soil biogeochemistry parameterizations in Earth system models with observations, Global Biogeochem. Cycles, 28, 211-222, 2014a.

Wieder, W. R., Boehnert, J., Bonan, G. B., and Langseth, M.: Regridded Harmonized World Soil Database v1.2, available at: http: //daac.ornl.gov (last access: January 2015) from Oak Ridge National Laboratory Distributed Active Archive Center, Oak Ridge, Tennessee, USA, 2014b.

Wieder, W. R., Grandy, A. S., Kallenbach, C. M., and Bonan, G. B.: Integrating microbial physiology and physio-chemical principles in soils with the MIcrobial-MIneral Carbon Stabilization (MIMICS) model, Biogeosciences, 11, 3899-3917, doi:10.5194/bg11-3899-2014, 2014c.

Wilbur, H. M., Tinkle, D. W., and Collins, J. P.: Environmental Certainty, Trophic Level, and Resource Availability in Life History Evolution, The American Naturalist, 108, 805-817, 1974.

Xu, X., Thornton, P. E., and Post, W. M.: A global analysis of soil microbial biomass carbon, nitrogen and phosphorus in terrestrial ecosystems, Global Ecol. Biogeogr., 22, 737-749, 2013.

Zak, D. R., Tilman, D., Parmenter, R. P., Rice, C. W., Fisher, F. M., Vose, J., Milchunas, D., and Martin, C. W.: Plant production and soil microorganisms in late-successional ecosystems: A continental-scale study, Ecology, 75, 2333-2347, 1994.

Zimmerman, A. R. and Ahn, M. Y.: Organo-mineraleenzyme interaction and soil enzyme activity, in: Soil Enzymology, Soil Biology, edited by: Shukla, G. and Varma, A., vol. 22, SpringerVerlag, Berlin, pp. 271-292, 2011. 